\title{
Ground-ice stable isotopes and cryostratigraphy reflect late Quaternary palaeoclimate in the Northeast Siberian Arctic (Oyogos Yar coast, Dmitry Laptev Strait)
}

\author{
Thomas Opel ${ }^{1, a}$, Sebastian Wetterich ${ }^{1}$, Hanno Meyer ${ }^{1}$, Alexander Y. Dereviagin ${ }^{2}$, Margret C. Fuchs ${ }^{3}$, and \\ Lutz Schirrmeister ${ }^{1}$ \\ ${ }^{1}$ Alfred Wegener Institute Helmholtz Centre for Polar and Marine Research, Periglacial Research Section, \\ 14473 Potsdam, Germany \\ ${ }^{2}$ Geology Department, Lomonosov Moscow State University, Moscow, 119992, Russia \\ ${ }^{3}$ Helmholtz-Zentrum Dresden-Rossendorf, Helmholtz Institute Freiberg for Resource Technology, 09599 Freiberg, Germany \\ anow at: Department of Geography, Permafrost Laboratory, University of Sussex, Brighton, BN1 9RH, UK
}

Correspondence to: Thomas Opel (thomas.opel@awi.de,t.opel@sussex.ac.uk)

Received: 3 January 2017 - Discussion started: 9 January 2017

Accepted: 4 May 2017 - Published: 6 June 2017

\begin{abstract}
To reconstruct palaeoclimate and palaeoenvironmental conditions in the northeast Siberian Arctic, we studied late Quaternary permafrost at the Oyogos Yar coast (Dmitry Laptev Strait). New infrared-stimulated luminescence ages for distinctive floodplain deposits of the Kuchchugui Suite (112.5 $\pm 9.6 \mathrm{kyr})$ and thermokarst-lake deposits of the Krest Yuryakh Suite $(102.4 \pm 9.7 \mathrm{kyr})$, respectively, provide new substantial geochronological data and shed light on the landscape history of the Dmitry Laptev Strait region during Marine Isotope Stage (MIS) 5. Groundice stable-isotope data are presented together with cryolithological information for eight cryostratigraphic units and are complemented by data from nearby Bol'shoy Lyakhovsky Island. Our combined record of ice-wedge stable isotopes as a proxy for past winter climate conditions covers about 200000 years and is supplemented by stable isotopes of pore and segregated ice which reflect annual climate conditions overprinted by freezing processes. Our ice-wedge stable-isotope data indicate substantial variations in northeast Siberian Arctic winter climate conditions during the late Quaternary, in particular between glacial and interglacial times but also over the last millennia to centuries. Stable isotope values of ice complex ice wedges indicate cold to very cold winter temperatures about $200 \mathrm{kyr}$ ago (MIS7), very cold winter conditions about $100 \mathrm{kyr}$ ago (MIS5), very cold to moderate winter conditions between about 60 and $30 \mathrm{kyr}$
\end{abstract}

ago, and extremely cold winter temperatures during the Last Glacial Maximum (MIS2). Much warmer winter conditions are reflected by extensive thermokarst development during MIS5c and by Holocene ice-wedge stable isotopes. Modern ice-wedge stable isotopes are most enriched and testify to the recent winter warming in the Arctic. Hence, ice-wedgebased reconstructions of changes in winter climate conditions add substantial information to those derived from paleoecological proxies stored in permafrost and allow a distinction between seasonal trends of past climate dynamics. Future progress in ice-wedge dating and an improved temporal resolution of ice-wedge-derived climate information may help to fully explore the palaeoclimatic potential of ice wedges.

\section{Introduction}

The wide tundra areas of the northeast Siberian Arctic lowlands are characterized by deep permafrost that results from cold continental climate conditions in west Beringia during the late Pliocene and Pleistocene when this region remained non-glaciated (Schirrmeister et al., 2013). Ice complex (IC) deposits formed in polygonal tundra environments with syngenetic ice-wedge growth during different periods of the late Quaternary in non-glaciated Beringia (Tumskoy, 2012; Schirrmeister et al., 2013). The most prominent IC 
of late Pleistocene age is called Yedoma IC (MIS4-3), but older IC formations are known such as the Yukagir IC of MIS7 age (Schirrmeister et al., 2002a) and the Buchchagy IC of MIS5 age (Wetterich et al., 2016). The ice-rich permafrost in this area contains huge amounts of ground ice. Syngenetic ice wedges are the major component. Vertically foliated ice wedges are formed by polygonal frost cracking due to thermal contraction of soils in winter and the subsequent filling of cracks with water in spring (e.g. Leffingwell, 1915; Lachenbruch, 1962). Snowmelt is the main source of the water that enters the frost crack, quickly refreezes there due to the negative ground temperatures, and forms a vertical ice vein. Depending on climate and site-specific environmental conditions minor sources may include varying proportions of densified snow or hoar-frost accretion (St-Jean et al., 2011; Boereboom et al., 2013). The periodic repetition of frost cracking and ice-vein formation results in ice-wedge growth in width and, if synchronous to sedimentation at the surface (syngenetic ice wedges), also in height.

Ice wedges may serve as paleoclimate archives (e.g. Mackay, 1983; Vaikmäe, 1989; Meyer et al., 2002b; Vasil'chuk, 2013), in particular in regions with a limited availability of climate archives. They can be studied by means of stable isotopes (Mackay, 1983). Due to rapid freezing in the frost crack preventing fractionation (Michel, 1982), the isotopic composition of each single ice vein is directly linked to atmospheric precipitation, i.e. winter snow, and, therefore, indicative of the climate conditions during the corresponding cold season. However, isotopic fractionation in the snow cover might impact the stable-isotope composition of wedge ice as well but is considered to be negligible for the purpose of this study. Hence, the stable isotope ratios of oxygen $\left(\delta^{18} \mathrm{O}\right)$ and hydrogen $(\delta \mathrm{D})$ of wedge ice (in \%o vs. Vienna Standard Mean Ocean Water, VSMOW) are related to the condensation temperature of the precipitation (Meyer et al., 2015) and are, therefore, interpreted as proxies for the mean winter air temperature at the study site. More negative values reflect colder conditions and less negative values reflect warmer conditions. The $d$ excess $\left(d=\delta \mathrm{D}-8 \delta^{18} \mathrm{O}\right)$ (Dansgaard, 1964) is indicative of the evaporation conditions (i.e. relative humidity, sea surface temperature) in the moisture source region (Merlivat and Jouzel, 1979). In the last years, stable-isotope data from ice wedges have been progressively used to reconstruct past climate changes in Arctic permafrost regions in northern Siberia (Meyer et al., 2002a, b, 2015; Opel et al., 2011, 2017a; Wetterich et al., 2011, 2014, 2016; Vasil'chuk and Vasil'chuk, 2014; Streletskaya et al., 2015) as well as in Alaska (Meyer et al., 2010b; Lachniet et al., 2012; Schirrmeister et al., 2016) and in Canada (Fritz et al., 2012; Porter et al., 2016) on different timescales and with different temporal resolutions.

In contrast, intra-sedimental ice forming cryostructures (pore ice as well as segregated-ice lenses and layers) in syngenetic permafrost originate from the freezing of soil moisture in the seasonally thawed active layer. Soil moisture is fed by varying proportions of different water sources such as summer rain and winter snow as well as meltwater of the thawed active layer ice (Mackay, 1983; Vaikmäe, 1989). Additionally, soil moisture is subject to evaporation processes and numerous freeze-thaw cycles before it enters the perennially frozen state. Hence, the stable isotope composition of pore and segregated ice has undergone several fractionation processes until the final freezing during permafrost aggradation. It therefore cannot be interpreted straightforwardly as a climate proxy (Wetterich et al., 2014, 2016). Nevertheless, the isotopic composition of pore and segregated ice has been successfully interpreted in terms of general climate trends such as long-term warming or cooling (Schwamborn et al., 2006; Dereviagin et al., 2013; Porter et al., 2016).

In the Siberian Arctic Laptev Sea region, comprehensive studies of ice-wedge and partly pore- and segregated-ice stable isotopes of stratigraphic units accessible in coastal exposures have been carried out in the last years at the Mamontova Khayata section of the Bykovsky Peninsula (Meyer et al., 2002a) and on the south coast of Bol'shoy Lyakhovsky Island close to the Zimov'e River mouth (Meyer et al., 2002b). Selected stratigraphic units have been studied at Cape Mamontov Klyk (Boereboom et al., 2013), at Bol'shoy Lyakhovsky Island (Wetterich et al., 2011, 2014, 2016), at the Oyogos Yar Coast (Opel et al., 2011), and in the Lena River delta (Schirrmeister et al., 2003b, 2011a; Wetterich et al., 2008; Meyer et al., 2015). To verify the obtained palaeoclimate results on different timescales and to assess their spatial and temporal representativity, additional extensive groundice stable-isotope records are needed.

As for all climate archives, reliable chronologies are crucial for ground-ice-based palaeoclimate studies. However, direct dating of ice wedges (Vasil'chuk et al., 2000) is challenging, in particular for the pre-Holocene. Mostly, there is only little particulate organic material for radiocarbon dating preserved in ice wedges. Therefore, air-bubble $\mathrm{CO}_{2}$ and dissolved organic carbon enclosed in ice wedges have also been used for radiocarbon dating to overcome this issue (Lachniet et al., 2012). Moreover, the ages of late Pleistocene ice wedges are often close to or beyond the age limit of radiocarbon dating. However, new dating tools are in development and comprise Uranium isotopes (Ewing et al., 2015) as well as ${ }^{36} \mathrm{Cl} / \mathrm{Cl}^{-}$dating for Middle to Late Pleistocene ground ice (Blinov et al., 2009). In many cases, syngenetic ice wedges are only indirectly dated by age determination of the surrounding host sediments. The attribution of host sediments and ice wedges to stratigraphic units with distinct chronological information is often complicated and, hence, regional stratigraphic correlations are challenging (Wetterich et al., 2014).

To address the issue of temporal and spatial representativity of ground-ice stable-isotope records, we present in this paper new data from different late Quaternary stratigraphic and chronological units at the Oyogos Yar Coast of the Dmitry Laptev Strait. Based on new geochronological and 

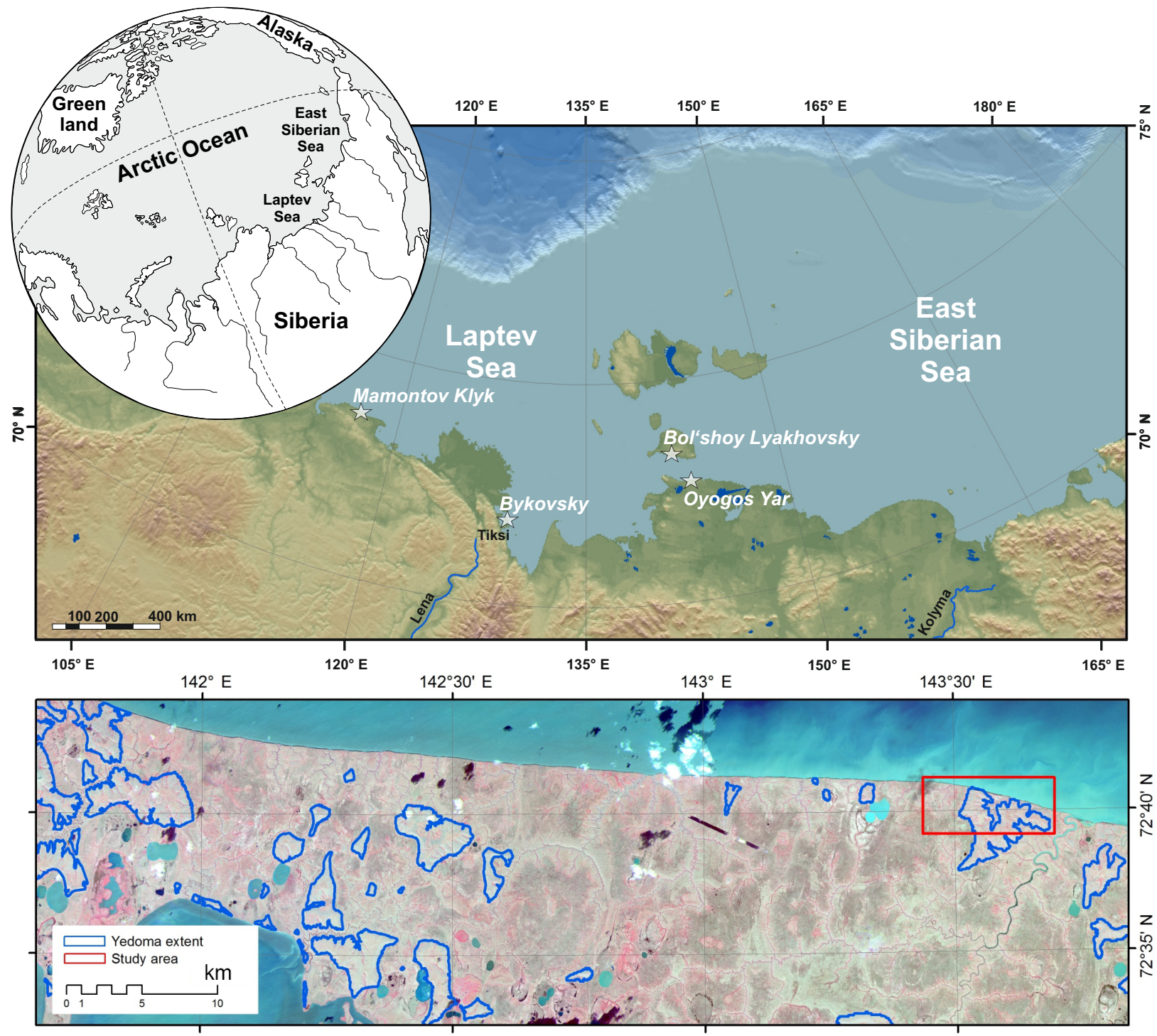

Figure 1. Overview map of the Laptev and East Siberian seas region (top) and detailed map the Oyogos Yar coast with extent of Yedoma Ice Complex remnants and the position of the coastal exposure presented in Fig. 2 (bottom, background image: false colour infrared RapidEye mosaic August 2010; modified after Günther et al., 2013).

cryolithological information we discuss the cryostratigraphy. We interpret the variability in new ice-wedge and pore- and segregated-ice stable isotope data and discuss the relevance of ground-ice stable isotopes in terms of paleoclimate and environmental history. We relate our ground-ice stable-isotope data to previously published data from Bol'shoy Lyakhovsky Island in order to generate a Dmitry Laptev Strait ground-ice isotope record and compare it to large-scale climate changes. Furthermore, we shed light on the potential of ice-wedge isotope data as tools for stratigraphic correlations between different study sites.

\section{Regional setting}

The Dmitry Laptev Strait connects the Laptev and East Siberian seas (Fig. 1), and its coasts have been the subject of geographical and geological research for more than 100 years (Bunge, 1887; von Toll, 1897; Romanovskii, 1958c, a, b). The north shore of the Dmitry Laptev Strait, i.e. the south coast of Bol'shoy Lyakhovsky Island, represents one of the best-studied Quaternary permafrost sites in northeast Siberia. To reconstruct the environmental dynamics of west Beringia since the mid-Pleistocene, extensive studies of the exposed frozen sediments and ground ice have been carried out (Arkhangelov et al., 1996; Kunitsky, 1996; Meyer et al., 2002b; Schirrmeister et al., 2002a, 2011b; Andreev et al., 


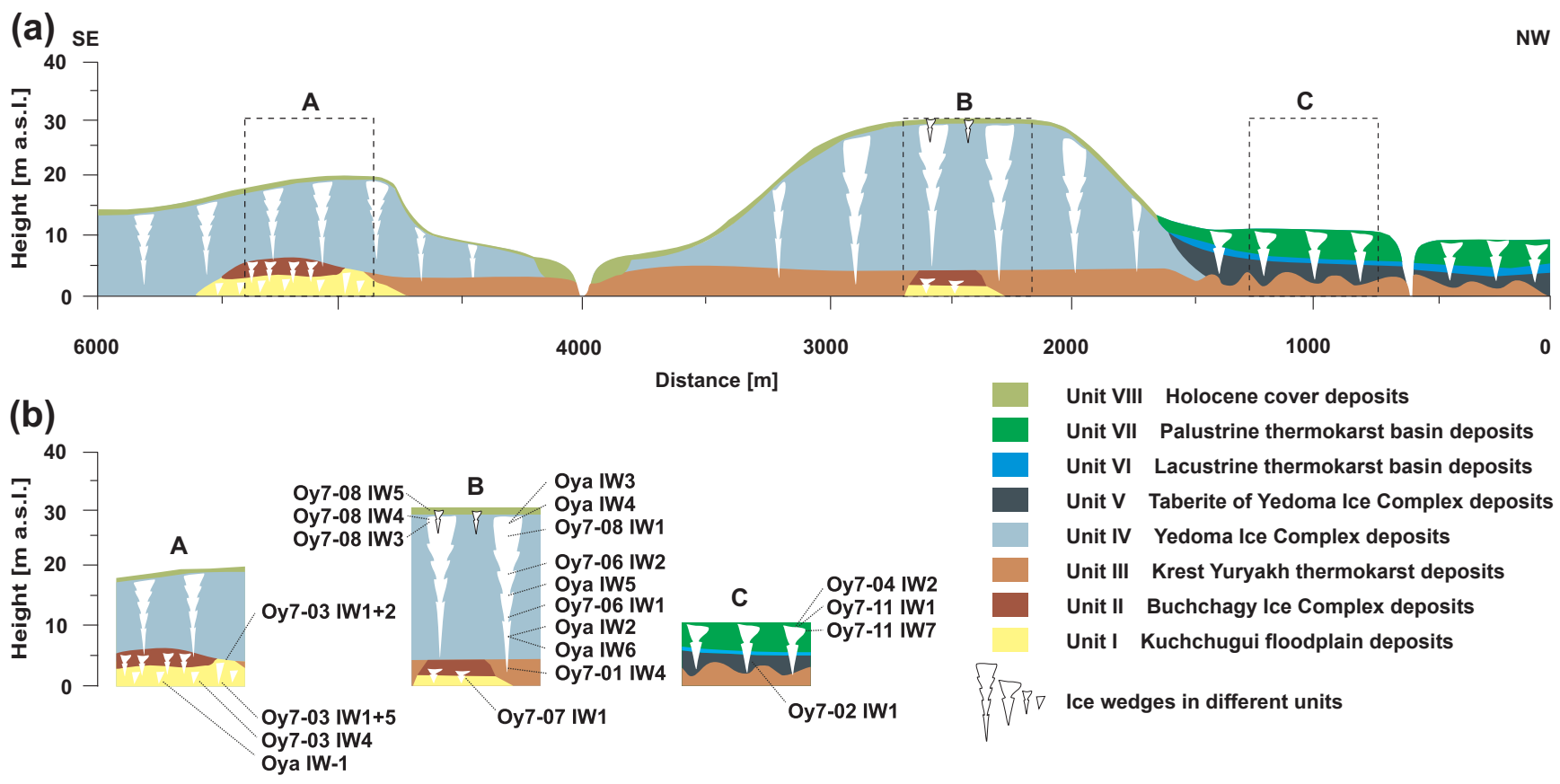

Figure 2. (a) Generalized overall stratigraphic sketch of the Oyogos Yar mainland coast about $30 \mathrm{~km}$ west of the Kondrat'eva River mouth indicating the main stratigraphic units, and (b) the approximate positions of the studied ice wedges in three insets (sequences $\mathrm{A}$ to $\mathrm{C}$ ). Updated and redrawn after Blinov et al. (2009).

2004, 2009, 2011; Tumskoy, 2012; Wetterich et al., 2009, 2011, 2014, and 2016 and references therein). In addition, the permafrost exposures of the Oyogos Yar mainland coast at the south shore of the Dmitry Laptev Strait have been studied, but less extensively (Ivanov, 1972; Gravis, 1978; Konishchev and Kolesnikov, 1981; Kaplina and Lozhkin, 1984; Tomirdiaro, 1984; Nagaoka et al., 1995; Wetterich et al., 2009; Kienast et al., 2011; Opel et al., 2011; Schirrmeister et al., 2011b; Rudaya et al., 2015, and references therein).

Interglacial and interstadial warm periods promote extensive permafrost thaw and subsequent surface subsidence mainly due to ground-ice melt. Such processes, termed thermokarst (e.g. Kaplina, 2009), have substantially influenced the study area during the last interglacial and since the late glacial-Holocene transition. Thawed and refrozen deposits are called taberite or taberal deposits (Kaplina, 2009) and underlie thermokarst-lake deposits (Fig. 2). Due to varying deposition regimes over time as well as spatially and temporally variable patterns of permafrost degradation (and also aggradation) during warm periods, permafrost sequences are often not continuous. This often complicates geochronological interpretations as deposits of consecutive late Quaternary periods may not be found superimposed upon each other but at laterally different positions and in different altitudes.

Following Tumskoy (2012), perennially frozen deposits exposed at the Dmitry Laptev Strait span from MIS7 to the Holocene (Table 1). Yedoma Ice Complex deposits (MIS $3-$ 2) are preserved in sections elevated up to $35 \mathrm{~m}$ a.s.l., while thermokarst basins up to $15 \mathrm{~m}$ a.s.l. high exhibit lacustrine and palustrine deposits of the late glacial and Holocene periods. Lacustrine deposits of the Krest Yuryakh Suite, which are commonly assigned to the last interglacial (Wetterich et al., 2009; Kienast et al., 2011; Tumskoy, 2012) as well as the Buchchagy Ice Complex (MIS 5e-b; Wetterich et al., 2016) are preserved either below Yedoma Ice Complex or below late glacial to Holocene thermokarst-lake and thermokarstbasin palustrine deposits (Fig. 2). The stratigraphic position of floodplain deposits assigned to both the Kuchchugui Suite (MIS6; Tumskoy, 2012) and the Zyryanian (MIS4) (Andreev et al., 2004, 2009) is still under debate.

The main landscape elements, i.e. Yedoma Ice Complex uplands as well as thermokarst basins (alasses) may be cut by thermo-erosional gullies and river valleys and are subject to rapid coastal erosion processes (Günther et al., 2013) that form steep coastal bluffs. Depending on the prevailing type of coastal erosion, thaw slumps may affect Yedoma Ice Complex deposits, shaping a thermo-terrace with thermokarst mounds (remaining sedimentary polygon-centre fillings after melting of ice wedges surrounding an ice-wedge polygon; baydzherakhs) in front of a steep wall with exposed ice wedges (Fig. 3).

\section{Material and methods}

The work presented here is based on material and observations of a 1-day reconnaissance trip in 2002 (Schirrmeister et 


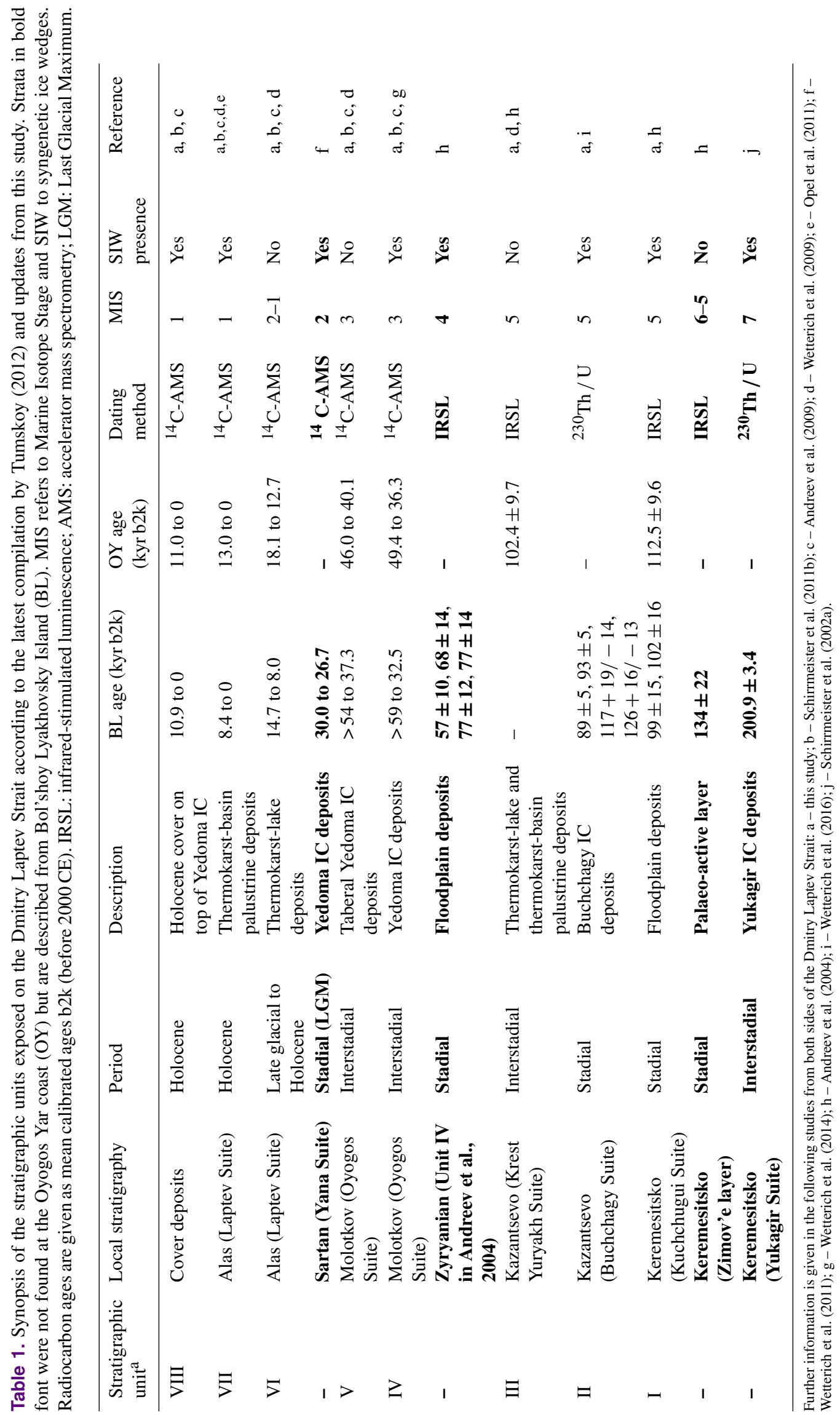



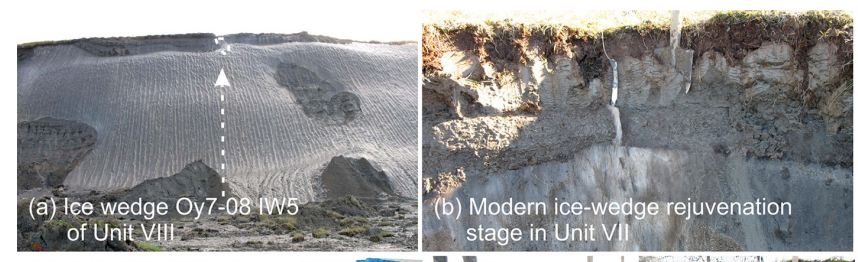

(c) Units V to VII in thermokarst basin
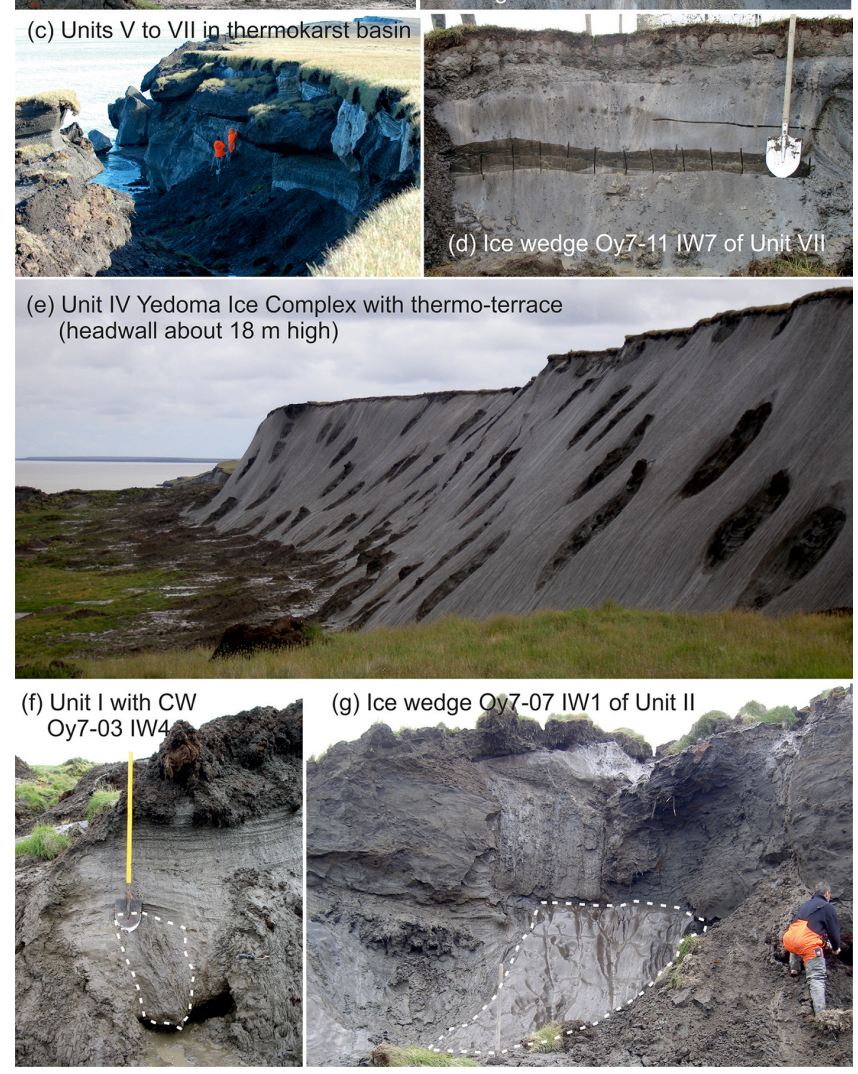

Figure 3. Photographs of selected outcrops and ice wedges of different units. $\mathrm{CW}$ means composite wedge.

al., 2003a) and a follow-up 4-week expedition to the Oyogos Yar coast in 2007 (Schirrmeister et al., 2008b) during which about $6 \mathrm{~km}$ of the Oyogos Yar coastline were studied (between $72.683^{\circ} \mathrm{N}, 143.475^{\circ} \mathrm{E}$ and $72.672^{\circ} \mathrm{N}, 143.635^{\circ} \mathrm{E}$ ).

\subsection{Fieldwork}

After overview surveys along the coastal bluffs ice wedges and sediment profiles from all exposed stratigraphic units were selected for extensive investigations and firstly described, photographed, and sketched.

After cleaning the exposures from thawed material and debris, horizons were cryolithologically described (Murton and French, 1994; French and Shur, 2010; Murton, 2013) and samples were taken by axe and hammer in sub-profiles. The weight of the frozen sample compared to the weight of the sample after oven-drying was used to calculate the gravimetric ice content of the sediments, expressed as weight percentage (wt \%) (Van Everdingen, 1998). Values higher than $100 \mathrm{wt} \%$ indicate ice oversaturation. From thawed sediment samples with supernatant water, we took samples for analysing the stable isotope composition of pore and segregated ice.

A handheld drilling machine (HILTI TE 5 A) equipped with a core bit was used to obtain frozen sediment cores $\left(150-290 \mathrm{~cm}^{3}\right)$ from profiles Oy7-07 (at $1.5 \mathrm{ma}$ a.s.l.) and Oy7-08 (at $4.0 \mathrm{~m}$ a.s.1.) for luminescence dating. Samples were protected from sunlight by using opaque plastic cylinders and sample bags. The sediment of the immediate surroundings of core positions was taken for high-purity Germanium (HPGe) low-level gamma spectrometry of radionuclide concentrations. Subsequent material processing and analyses were performed at the Luminescence Laboratory of the Technical University Bergakademie Freiberg (Germany).

In total, we sampled 44 ice wedges from all exposed stratigraphic units: 7 in 2002 and 37 in 2007 (Fig. 2). Stable isotope samples from ice wedges were taken by chain saw, by axe, or by ice screws (in horizontal profiles covering the entire width of the studied ice wedges) along the ice wedge's growth direction (i.e. the profiles perpendicularly cut frost-cracking direction and near-vertical individual ice veins). The sampling resolution varied from about 1 and about $30 \mathrm{~cm}$ between different ice wedges (but remained constant within individual ice wedges), depending on fieldwork logistics, sampling tools, and specific research questions. The samples were either melted on site with meltwater stored in tightly closed $30 \mathrm{~mL}$ PE bottles or transported as blocks in frozen state to the cold laboratory of the Alfred Wegener Institute (AWI) in Potsdam for sub-sampling. The melted samples were stored in a cool place $\left(\sim 5^{\circ} \mathrm{C}\right)$ before analysing the stable isotope composition. Organic material enclosed in ice wedges was picked out either in the field or in the AWI cold laboratory for radiocarbon dating.

\subsection{Radiocarbon dating}

Organic remains enclosed in ice-wedge samples (unidentified plant remains and lemming droppings) as well as plant remains from sediment samples were radiocarbon dated using the accelerator mass spectrometry (AMS) facilities at the Leibniz Laboratory for Radiometric Dating and Stable Isotope Research (Kiel University, Germany) (Grootes et al., 2004), CologneAMS (University of Cologne, Germany) (Dewald et al., 2013; Rethemeyer et al., 2013), and Poznań Radiocarbon Laboratory (Adam Mickiewicz University, Poznań, Poland) (Goslar et al., 2004). Conventional ${ }^{14} \mathrm{C}$ ages were calculated according to Stuiver and Polach (1977). Calibrated ages were determined as yr b2k (before $2000 \mathrm{CE}$ ) using Oxcal 4.2 (Bronk Ramsey, 2009) based on the IntCal13 dataset (Reimer et al., 2013). 


\subsection{Infrared-stimulated luminescence (IRSL) dating}

The cores were processed for quartz and feldspar at target grain size fractions of 20-40, 40-63, 63-100, and 90$160 \mu \mathrm{m}$. Lacking coarse-grained material $(>100 \mu \mathrm{m})$ and quartz optically stimulated luminescence (OSL) signals close to saturation required focusing on feldspar infraredstimulated luminescence (IRSL) of the grain size fraction 63-100 $\mu \mathrm{m}$. Carbonates and organics were removed using $10 \% \mathrm{HCl}$ and $30 \% \mathrm{H}_{2} \mathrm{O}_{2}$, respectively. Feldspar flotation (0.2\% HF, pH 2.4-2.7, dodecylamine) removed the quartz from sample extracts and subsequent density separation enriched $\mathrm{K}$ feldspars $\left(2.53-2.58 \mathrm{~g} \mathrm{~cm}^{-3}\right)$. Etching $(10 \% \mathrm{HF}$, $5 \mathrm{~min}$ ) removed the outer $10 \mu \mathrm{m}$ layer of individual grains.

Aliquots of 2 and $1 \mathrm{~mm}$ diameter reflect the trade-off between low grain number per aliquot (reduced averaging of inter-grain variations) and sufficient luminescence signal intensities. The IRSL signals of feldspars were measured using a TL/OSL DA-20 reader (Bøtter-Jensen et al., 2003) equipped with a ${ }^{90} \mathrm{Sr}$ beta irradiation source ( $4.95 \mathrm{~Gy} \mathrm{~min}^{-1}$ ).

Signals were stimulated at $870 \mathrm{~nm}$ (IR diodes, $125^{\circ} \mathrm{C}$ for $100 \mathrm{~s}$ ) and detected through a $410 \mathrm{~nm}$ optical interference filter (Krbetschek et al., 1997). The measurement sequence followed the single-aliquot regenerative-dose (SAR) protocol according to Murray and Wintle (2000), including cycles to record recycling ratios and recuperation and to correct for sensitivity changes. Appropriate measurement conditions were evaluated and adjusted based on preheat tests and dose-recovery tests (Murray and Wintle, 2003). The processing of measured data and statistical analyses were performed using the software Analyst v4.31.7 (Duller, 2015) and the R package "Luminescence" (Kreutzer et al., 2012), version 0.6.4. The small dataset $(n=5)$ restricted age modelling to a simple measure of central tendency, i.e. the arithmetic mean. The large dataset $(n=49)$ showed no evidence of insufficient bleaching due to low scatter (standard deviation below $10 \%$ ) and low skewness $(<0.5)$ of equivalent doses and, hence, suggested palaeodose calculation based on the Central Age Model (CAM) (Galbraith et al., 1999). Final IRSL ages, including dose rate modelling, were estimated using the software ADELE (Kulig, 2005). For the determination of the mineral-internal dose rate of the $\mathrm{K}$ feldspars, a potassium content of $12.5 \pm 0.5 \%$ was assumed (Huntley and Baril, 1997).

\subsection{Stable-isotope analysis}

The equilibrium technique was used to prepare ice-wedge as well as pore- and segregated-ice samples for stable-isotope analysis. Stable oxygen $\left(\delta^{18} \mathrm{O}\right)$ and hydrogen $(\delta \mathrm{D})$ isotope ratios were measured on a Finnigan 215 MAT Delta-S at AWI Potsdam. The values are given in delta per mil notation $(\delta, \% o)$ relative to the VSMOW standard. Based on longterm standard measurements, the reproducibility of $1 \sigma$ is better than $\pm 0.1 \%$ o for $\delta^{18} \mathrm{O}$ and $\pm 0.8 \%$ o for $\delta \mathrm{D}$ (Meyer et al.,
2000). The deuterium excess $d$ (Dansgaard, 1964) was calculated by $d=\delta \mathrm{D}-8 \times \delta^{18} \mathrm{O}$.

For this study, we considered only ice wedges with a clear stratigraphic relation to one of the studied units and at least three samples. Exceptions were made only for a small Holocene ice wedge at the top of the Yedoma Ice Complex (two samples) as well as for narrow modern ice wedges, i.e. single veins or groups of ice veins representing the youngest ice-wedge growth stage (one to two samples). Following this, from the 44 sampled ice wedges, we considered in the following only 28 . Partly, ice-wedge data were only interpreted as groups (i.e. recent ice-wedge parts and modern ice veins).

In several cases, stable-isotope data, preferentially those from samples at the edge of ice wedges showed clear signs of post-genetic fractionation processes owing to exchange processes between wedge ice and surrounding sediments. The respective data are characterized by distinctly elevated $\delta^{18} \mathrm{O}$ and $\delta \mathrm{D}$ values and decreased $d$ excess values and were excluded from further analysis and interpretation.

Similar to ice wedges, we considered only pore- and segregated-ice stable-isotope data with a clear attribution to one of the studied units and only units with at least three data points.

\section{Results}

Within this paper, we focus on our extensive studies of cryostratigraphy and, in particular, ground-ice stable isotopes. For more detailed results and discussion of distinct sediment profiles, we refer to Wetterich et al. (2009), Schirrmeister et al. (2011b), and Wetterich et al. (2016). We also adopted most radiocarbon ages derived from sediment samples from these papers.

\subsection{Cryostratigraphy and geochronology}

Eight cryostratigraphic units were distinguished during fieldwork at the Oyogos Yar coast (Table 1, Fig. 2). The studied ice wedges were assigned to five of the units based on field observations.

\subsubsection{Unit I}

The oldest unit studied at the Oyogos Yar coast is represented by floodplain deposits related to the Kuchchugui Suite. The deposits consist of brownish-grey laminated silty sands and contain peat inclusions and in situ grass roots. Unit 1 varies in ice content (31-108 wt \%; mean $52 \mathrm{wt} \%$; Table 2). Cryostructures include structureless cryostructure (no ice inclusions visible by naked eye) as well as horizontal ice layers (10-20 mm thick, 50-100 mm apart) with wavy lenticular and irregular reticulate ice lenses ( $1 \mathrm{~mm}$ thick). A darkbrown peat soil layer covers the sequence which includes coarse ( $>1 \mathrm{~mm}$ thick) irregular reticulate ice lenses between ice layers (10-20 $\mathrm{mm}$ thick and $50 \mathrm{~mm}$ apart). 
Table 2. Gravimetric ice content (minimum, mean, and maximum values; standard deviations) of the sediments, expressed as weight percentage (wt \%) (Van Everdingen, 1998).

\begin{tabular}{lrrrrr}
\hline $\begin{array}{l}\text { Stratigraphic } \\
\text { unit }\end{array}$ & $\begin{array}{r}\text { Samples } \\
(n)\end{array}$ & $\begin{array}{r}\text { Ice content } \\
\min (\mathrm{wt} \% \text { o) }\end{array}$ & $\begin{array}{r}\text { Ice content } \\
\text { mean }(\mathrm{wt} \% \text { ) }\end{array}$ & $\begin{array}{r}\text { Ice content } \\
\max (\mathrm{wt} \% \text { o })\end{array}$ & $\begin{array}{r}\text { Ice content } \\
\text { SD (wt \%o) }\end{array}$ \\
\hline VIII & 3 & 54.4 & 92.4 & 118.0 & 33.6 \\
VII & 6 & 52.4 & 119.3 & 183.3 & 43.5 \\
VI & 3 & 29.4 & 46.3 & 70.8 & 21.7 \\
V & 3 & 32.7 & 39.0 & 42.3 & 5.4 \\
IV & 24 & 24.6 & 118.7 & 241.7 & 58.8 \\
III & 31 & 15.0 & 36.2 & 66.4 & 10.2 \\
II & 12 & 25.6 & 163.7 & 793.8 & 224.2 \\
I & 6 & 30.9 & 52.3 & 108.5 & 28.9 \\
\hline
\end{tabular}

Table 3. IRSL samples Oy7-07-01 (Unit I) and Oy7-08-25 (Unit III) with all palaeodose and dose rate parameters used for final age calculation ( $n$ : number of aliquots; CAM: Central Age Model from Galbraith et al. (1999); m a.s.1.: metres above sea level; m b.s.: metres below surface).

\begin{tabular}{|c|c|c|c|}
\hline ID & & Oy7-07-01 & Oy7-08-25 \\
\hline \multicolumn{4}{|l|}{ Palaeodose parameters } \\
\hline$n$ & & 49 & 5 \\
\hline Mean & (Gy) & $288.4 \pm 4.0$ & $270.8 \pm 8.0$ \\
\hline Standard deviation & $(\%)$ & 9.6 & 6.6 \\
\hline Skewness & & 0.4 & 0.2 \\
\hline Coefficient of variation & $(\%)$ & 6.7 & 6.3 \\
\hline CAM & (Gy) & $286.9 \pm 3.9$ & - \\
\hline \multicolumn{4}{|l|}{ Dose rate parameters } \\
\hline${ }^{238} \mathrm{U}$ & $\left(\mathrm{Bq} \mathrm{kg}^{-1}\right)$ & $24.77 \pm 2.55$ & $33.43 \pm 0.88$ \\
\hline${ }^{232} \mathrm{Th}$ & $\left(\mathrm{Bq} \mathrm{kg}^{-1}\right)$ & $31.75 \pm 1.12$ & $38.14 \pm 1.88$ \\
\hline${ }^{40} \mathrm{~K}$ & $\left(\mathrm{~Bq} \mathrm{~kg}^{-1}\right)$ & $572.95 \pm 7.99$ & $528.11 \pm 3.05$ \\
\hline Water content & $(\%)$ & 30.5 & 27.5 \\
\hline Height/cover thickness & (m a.s.1./m b.s.) & $1.5 / 24$ & $4 / 22$ \\
\hline Total dose rate & $\left(\mathrm{Gy} \mathrm{kyr}^{-1}\right)$ & 2.6 & 2.6 \\
\hline Age & (kyr) & $112.5 \pm 9.6$ & $102.4 \pm 9.7$ \\
\hline
\end{tabular}

Syngenetic ice wedges in Unit I are rather small and can be divided into two types. The first type occurs in the lower part of this unit and consists of 0.3 to $0.75 \mathrm{~m}$ wide composite wedges (sand-ice wedges) composed of alternating ice and sand veins ( 1 to $10 \mathrm{~mm}$ wide). They exhibit rounded truncated heads and are buried by the upper part of Unit I. The second type is represented by intersecting multistage ice wedges, i.e. composite wedges that transform upwards into regular syngenetic ice wedges 0.5 to $1 \mathrm{~m}$ wide. Their clean, transparent wedge ice contains many vertically oriented air bubbles (1-5 $\mathrm{mm}$ in diameter) and pronounced ice veins of 3-6 mm thickness. Additionally, epigenetic ice wedges from the overlying Unit II penetrate into the Kuchchugui deposits.

IRSL analyses of feldspars (63-100 $\mu \mathrm{m} ; n=49$; CAM) yielded a deposition age of $112.5 \pm 9.6 \mathrm{kyr}$ for sample Oy707-01. Suitable IRSL signal properties are indicated by high signal intensity, good reproducibility, and low recuperation.
This is confirmed by a low coefficient of variation in doses recovery tests $(6.7 \%)$. The low standard deviation and low skewness value indicate no bleaching issues (Table 3) and suggest a reliable IRSL age estimation.

Radiocarbon dating of moss peat from the upper horizon sampled directly above composite wedge Oya IW1 revealed a non-finite age of $>44.5 \mathrm{cal} \mathrm{kyr} \mathrm{b2k}$ for the leached residue and a mean age of $45.2 \mathrm{cal} \mathrm{kyr} \mathrm{b2k}$ for humic acid (Table 4).

\subsubsection{Unit II}

Unit II represents the Buchchagy Ice Complex. It is represented by 6 to $8 \mathrm{~m}$ thick brown to grey silty sands with peat inclusions and two distinct peaty horizons up to $1 \mathrm{~m}$ thick about $3 \mathrm{~m}$ apart (Wetterich et al., 2016). 
Table 4. Radiocarbon ages and calibrated ages (95.4\% probability) of sediment samples from Oyogos Yar coast. NaN indicates that the calibration failed and no calibrated age is available.

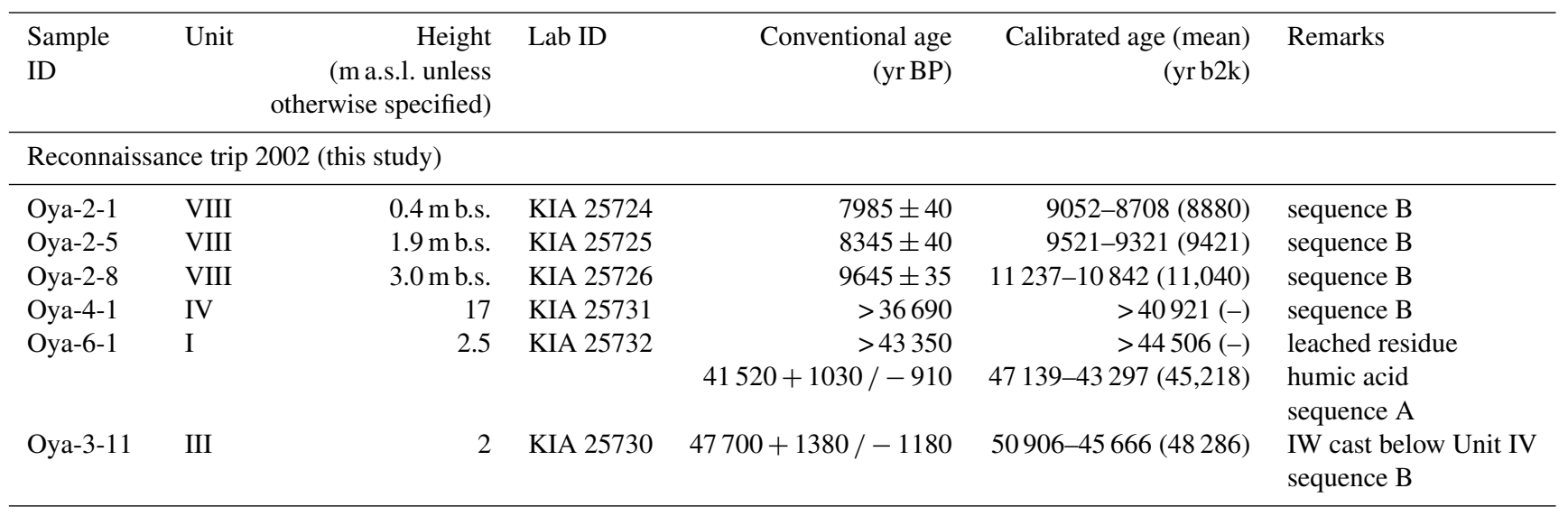

Field campaign 2007 - sequence A: Buchchagy Ice Complex (Wetterich et al., 2016)

\begin{tabular}{|c|c|c|c|c|c|}
\hline Оу7-10-09 & II & 6.2 & Poz-51638 & $>49000$ & - $\quad$ upper peat \\
\hline Oy7-10-04 & II & 3.3 & Poz-51637 & $>51000$ & lower peat \\
\hline
\end{tabular}

Field campaign 2007 - sequence B: Yedoma Ice Complex (Schirrmeister et al., 2011b)

\begin{tabular}{rlrrrr}
\hline Oy7-08-63 & IV & 27.0 & KIA 37638 & $32220+370 /-350$ & $37199-35324(36262)$ \\
Oy7-08-62 & IV & 26.5 & KIA 37637 & $34630+420 /-400$ & $40208-38435(39322)$ \\
Oy7-08-57 & IV & 24.0 & KIA 37636 & $38600+930 /-830$ & $44365-41551(42958)$ \\
Oy7-08-53 & IV & 22.0 & KIA 37635 & $44900+1230 /-1060$ & NaN-46593(NaN) \\
Oy7-08-47 & IV & 19.2 & KIA 37634 & $40850+1750 /-1440$ & $48313-42357(45335)$ \\
Oy7-08-42 & IV & 17.1 & KIA 37633 & $48540+1750 /-1440$ & $53128-45594(49361)$ \\
Oy7-08-38 & IV & 15.5 & KIA 37632 & $44840+1270 /-1100$ & NaN-46238(NaN) \\
Oy7-08-37 & IV & 12.0 & KIA 37631 & $43860+1270 /-1090$ & $49686-45380(47533)$ \\
Oy7-08-32 & IV & 9.5 & KIA 37630 & $41420+1040 /-920$ & $46909-43225(45067)$ \\
\hline
\end{tabular}

Field campaign 2007 - sequence C: taberal Yedoma Ice Complex to Holocene (Wetterich et al., 2009)

\begin{tabular}{llrlrr}
\hline Oy7-11-14 & VII & 11.1 & KIA 35234 & $3325 \pm 35$ & \multicolumn{1}{c}{$3690-3513(3602)$} \\
Oy7-11-12 & VII & 10.1 & KIA 35233 & $8335 \pm 45$ & $9524-9198(9361)$ \\
Oy7-11-10 & VII & 8.8 & KIA 35232 & $8260 \pm 40$ & $9461-9144(9303)$ \\
Oy7-11-09 & VII & 8.6 & KIA 36687 & $9985 \pm 35$ & $11665-11322(11494)$ \\
Oy7-11-08 & VII & 8.3 & KIA 36686 & $11145 \pm 40$ & $13155-12942(13049)$ \\
Oy7-11-07 & VI & 8.0 & KIA 35231 & $14830+70 /-60$ & $18299-17899(18099)$ \\
Oy7-11-06 & VI & 7.7 & KIA 36688 & $10720+40 /-35$ & $12781-12651(12716)$ \\
Oy7-11-04 & VI & 7.1 & KIA 35230 & $11,995 \pm 50$ & $14062-13786(13924)$ \\
Oy7-11-03 & V & 6.8 & KIA 35229 & $41290+2370 /-1830$ & $49458-42469(45964)$ \\
Oy7-11-01 & V & 6.0 & KIA 35228 & $36580+1090 /-960$ & $40863-39333(40098)$ \\
\hline
\end{tabular}

The lower peaty horizon consists of brownish blue grey silty sand with numerous peat inclusions up to $300 \mathrm{~mm}$ in diameter. Ice layers $(30 \mathrm{~mm}$ thick) and wavy lenticular cryostructures (1-2 mm thick, $10-15 \mathrm{~mm}$ apart) in between are typical. The ice content varies between 25 and $112 \mathrm{wt} \%$ (Table 2) in the mineral part while the peaty deposits are ice oversaturated (113-793 wt \%). Brownish grey silty sand covers the lower peaty horizon and contains fewer peaty remains and some twigs. Horizontal ice layers (5-20 mm thick, 50$100 \mathrm{~mm}$ apart) and curved lenticular and layered cryostructures (up to $2 \mathrm{~mm}$ thick) are observed. The upper peaty horizon is similar to the lower one as described above.
Unit II contains syngenetic ice wedges 2 to $4 \mathrm{~m}$ wide and several metres deep that penetrate into Unit I. Partly they are truncated and buried below grey loam with many peat inclusions, likely representing the lower peat horizon. The wedge ice of rather dirty yellowish-grey colour contains numerous mineral inclusions and air bubbles of $1-5 \mathrm{~mm}$ in diameter. Ice-vein thickness is about 3-5 mm.

The only dating results available are infinite radiocarbon ages ( $>51$ kyr BP and $>49$ kyr BP; Table 4 ) for the two distinctive peaty layers (Wetterich et al., 2016). At the southern coast of Bol'shoy Lyakhovsky Island, opposite to the Oyogos Yar coast, the respective peaty horizons of the Buchchagy Ice 
Complex show infinite radiocarbon ages as well, whereas radioisotope $\left({ }^{230} \mathrm{Th} / \mathrm{U}\right)$ disequilibria dating of peat revealed ages of $126+16 /-13$ and $118+19 /-14 \mathrm{kyr}$ for the lower, and $93 \pm 5$ and $89 \pm 5 \mathrm{kyr}$ for the upper peat horizon (Wetterich et al., 2016). This geochronological information can be transferred to the Oyogos Yar coast. The chronostratigraphic link is supported by ice-wedge stable isotope data (see Sect. 5.2).

\subsubsection{Unit III}

Unit III refers to deposits of the Krest Yuryakh Suite that is commonly related to the last interglacial. Unit III comprises two types of deposits, both associated with thermokarst-lake development. The first type represents a succession of an ancient lake margin. It consists of bedded dark grey to greyish brown silts, partly rippled. Mollusc shells as well as plant detritus layers and plant inclusions (partly wood fragments) are common. The upper part shows decreasing plant detritus content and numerous mollusc shells. The cryostructure is irregular reticulate (1-2 $\mathrm{mm}$ thick). The second type represents lacustrine sediments filling ice-wedge casts above taberal deposits. The lacustrine deposits consist of bedded grey clayey sandy silts with brown peat lenses and alternating plant detritus layers. The cryostructures are layered (1 mm thick) and oriented parallel to the sedimentary bedding. For both kinds of deposits, the ice content varies from 15 to $66 \mathrm{wt} \%$ (mean $36 \mathrm{wt} \%$; Table 2). The underlying taberal deposits of grey silts exhibit a structureless cryostructure.

No syngenetic ice wedges were found, but toes of younger epigenetic ice wedges, presumably related to Unit IV, were partly present.

IRSL analyses of sample Oy7-08-25 could only be based on a few aliquots $(n=5)$ due to the limited material in the suitable grain size fraction $(63-100 \mu \mathrm{m})$. Nevertheless, the low coefficient of variation $(6.3 \%)$ in dose-recovery tests $(n=5)$ indicates appropriate luminescence properties and measurement conditions. Reliable feldspar properties are further supported by high signal intensity, good reproducibility, low standard deviation, and low skewness (Table 3). The IRSL results date Unit III to $102.4 \pm 9.7 \mathrm{kyr}$.

A mean radiocarbon age of $48.3 \mathrm{cal} \mathrm{kyr} \mathrm{b2k}$ was obtained from leached residue of wood in sample Oya-3-11 from an ice-wedge cast (Table 4).

\subsubsection{Unit IV}

Unit IV represents the Yedoma Ice Complex that constitutes of grey-brown sandy silts with small $(20 \times 20 \mathrm{~mm})$ and larger (up to $200 \times 400 \mathrm{~mm}$ ) peat inclusions, which originate from buried cryosols, as well as twig fragments, grass roots, and fine, distributed plant detritus. The cryostructures are horizontally layered (1-2 mm thick, $30-100 \mathrm{~mm}$ apart) and irregular reticulate ( $2-3 \mathrm{~mm}$ thick, $10-30 \mathrm{~mm}$ long) between the ice layers. The gravimetric ice content ranges from 25 to more than $240 \mathrm{wt} \%$ (mean $119 \mathrm{wt} \%$; Table 2). Huge syngenetic ice wedges up to $8-10 \mathrm{~m}$ wide in the higher sections ( $2-5 \mathrm{~m}$ in the lower sections) have vertical extents of more than $20 \mathrm{~m}$. The wedge ice is mostly dirty grey as typical for Yedoma Ice Complex ice wedges with varying sediment contents but partly also milky white, indicating a much higher number of small air bubbles. Vertically oriented ice veins are mostly between 1 and $5 \mathrm{~mm}$ wide.

According to mean radiocarbon ages the Yedoma Ice Complex was deposited in the time period between about 49.4 and 36.3 cal kyr b2k (Table 4). Several age reversals have been found; hence no clear age-depth relationship could be established.

\subsubsection{Unit $\mathrm{V}$}

In the vast thermokarst basin, Unit $\mathrm{V}$ consists of taberal Yedoma Ice Complex deposits, which thawed below a thermokarst lake and refroze after lake drainage or desiccation. Unit $\mathrm{V}$ is represented by light-grey silts with very little plant detritus. The top of Unit $\mathrm{V}$ consists of a paleosol layer with twigs and peat inclusions. The cryostructure is wavy and layered ( $1 \mathrm{~mm}$ thick, $50-150 \mathrm{~mm}$ long, $10-20 \mathrm{~mm}$ apart) and the gravimetric ice content is around $40 \mathrm{wt} \%$ (Table 2). Whereas no syngenetic ice wedges were found, the epigenetic toes of ice wedges (related to Unit VII) were partly observed.

Radiocarbon ages of taberal Yedoma Ice Complex deposits revealed mean ages of about 46.0 and 40.1 cal kyr b2k (Table 4), which correspond to the period of Yedoma Ice Complex deposition, not the time of thermokarst-lake development.

\subsubsection{Unit VI}

The late glacial to Holocene sequence starts with about $2 \mathrm{~m}$ lacustrine deposits of Unit VI, partly filling ice-wedge casts. The cryostructure is layered and the gravimetric ice content is 30-70 wt \% (Table 2). Unit VI is characterized by alternating bedding of silty fine sand and plant detritus and also contains wood fragments and mollusc shells. The lake deposits are covered by a 20 to $30 \mathrm{~cm}$ thick peat horizon. No syngenetic ice wedges were found, but the lower parts of ice wedges of Unit VII were.

Radiocarbon dating revealed a late glacial age (means about 18.1 to 12.7 cal kyr b2k) of the thermokarst-lake deposits (Table 4).

\subsubsection{Unit VII}

The palustrine deposits of Unit VII consist of about $3 \mathrm{~m}$ of ice-rich greyish sandy silts, partly containing peat lenses and a pronounced brown peat horizon of $30 \mathrm{~cm}$ thickness and wood remains (20-30 cm in diameter). The cryostructure is layered ( $1 \mathrm{~mm}$ thick, $20-30 \mathrm{~mm}$ long, $50-100 \mathrm{~mm}$ apart). 
Table 5. Radiocarbon ages and calibrated ages (95.4\% probability unless otherwise indicated) of organic remains in Holocene ice-wedge samples of Unit VII in sequence C. All samples were taken at a similar depth (about 1 to $1.5 \mathrm{~m}$ below surface).

\begin{tabular}{|c|c|c|c|c|}
\hline $\begin{array}{l}\text { Sample } \\
\text { ID }\end{array}$ & Lab ID & $\begin{array}{r}\text { Conventional age } \\
(\mathrm{yr} \mathrm{BP})\end{array}$ & $\begin{array}{r}\text { Calibrated age (mean) } \\
(\mathrm{yr} \text { b2k) }\end{array}$ & Remarks \\
\hline \multicolumn{5}{|c|}{ Ice wedge Oy7-04 IW2 (Oy7-04-...) (Opel et al., 2011, 2017a) } \\
\hline 205 & COL3997.1.1 & $1607 \pm 49$ & $1659-1438(1549)$ & \multirow{7}{*}{ Reworked } \\
\hline 242 & KIA 35630 & $523 \pm 43$ & $690-551(621)$ & \\
\hline 247 & KIA 35631 & $3518 \pm 31$ & $3927-3751(3839)$ & \\
\hline 263 & KIA 35632 & $412 \pm 30$ & $570-380(475)$ & \\
\hline 267 & KIA 35633 & $258 \pm 51$ & $519-193(356)$ & \\
\hline 274 & KIA 35634 & $488 \pm 58$ & 696-382 (539) & \\
\hline 290 & KIA 35635 & $1479 \pm 106$ & $1659-1232(1446)$ & \\
\hline \multicolumn{5}{|c|}{ Ice wedge Oy7-11 IW1 (Oy7-11-...) (Opel et al., 2011) } \\
\hline 138 & KIA 35636 & $8959 \pm 43$ & $10278-9970(10124)$ & \multirow{3}{*}{$\begin{array}{l}\text { Redistributed } \\
\text { Redistributed }\end{array}$} \\
\hline 162 & KIA 35637 & $8300 \pm 43$ & 9486-9188 (9337) & \\
\hline 189 & KIA 35638 & $857 \pm 43$ & 956-737 (847) & \\
\hline \multicolumn{5}{|c|}{ Ice wedge Oy7-11 IW7 (Oy7-11-...) (Opel et al., 2017a) } \\
\hline 719 & KIA 40385 & $1858 \pm 60$ & $1976-1674(1825)$ & \multirow{7}{*}{$\begin{array}{l}\text { Post-bomb } \\
\text { ( } 84.5 \% \text { probability) }\end{array}$} \\
\hline 723 & KIA 40386 & $1868 \pm 36$ & $1931-1765(1848)$ & \\
\hline 740 & KIA 40387 & $1081 \pm 22$ & 1104-984 (1044) & \\
\hline 747 & KIA 40388 & $1098 \pm 24$ & $1100-1005(1053)$ & \\
\hline 796 & KIA 40390 & $\mathrm{~F}^{14} \mathrm{C} 1.2661 \pm 0.005$ & 20-18 (19) & \\
\hline 820 & KIA 40391 & $225 \pm 25$ & 358-198 (278) & \\
\hline Нy27 & COL1925.1.1 & $1579 \pm 43$ & $1606-1429(1518)$ & \\
\hline Ну31 & KIA 40393 & $14,200 \pm 71$ & $17575-17108$ (17 342) & Redistributed \\
\hline Ну40 & KIA 40394 & $6640 \pm 50$ & 7637-7487 (7562) & Redistributed \\
\hline
\end{tabular}

The gravimetric ice content is $50-180 \mathrm{wt} \%$ (mean $119 \mathrm{wt} \%$; Table 2). The recent polygonal surface of the thermokarst basin is mirrored by widely distributed and actively growing syngenetic ice wedges. They are up to $3.5 \mathrm{~m}$ wide and up to about $8 \mathrm{~m}$ high with toes that reach the taberal deposits of Unit V. Their ice is mostly transparent to milky white but sometimes also dirty grey due to a higher density of sediments and organic matter. Single ice veins are 1 to $10 \mathrm{~mm}$ wide. The ice of the most recent ice-wedge parts as well as of the modern rejuvenation stages (up to $8 \mathrm{~cm}$ wide and up to $20 \mathrm{~cm}$ high) is more milky white due to a higher number of small air bubbles.

The palustrine deposits in the thermokarst basin accumulated over the Holocene (about 11.5 to 3.6 cal kyr b2k) with the pronounced peat horizon dated to about $9.3 \mathrm{cal} \mathrm{kyr} \mathrm{b2k}$ (Table 4). Organic remains in ice-wedge samples indicate syngenetic ice-wedge growth over the late Holocene, i.e. since about $2.0 \mathrm{cal}$ kyr b2k (Table 5).

\subsubsection{Unit VIII}

Unit VIII constitutes the up to 1-2 m thick Holocene cover on top of the Yedoma Ice Complex. Unit VIII was only found in places representing the fillings of small initial thermokarst ponds (bylary). The deposits consist of brownish grey loam with numerous peat inclusions. The cryostructures are layered (10-20 mm thick, 20-50 $\mathrm{mm}$ apart) and irregular reticulate ( $1 \mathrm{~mm}$ thick). The gravimetric ice content is 54 to 118 wt \% (mean $92 \mathrm{wt} \%$; Table 2). The transition to the unfrozen uppermost active layer contains a $20-30 \mathrm{~mm}$ thick ice layer built of vertical ice needles. Unit VIII contains small, milky white syngenetic ice wedges less than $1 \mathrm{~m}$ wide whose toes penetrate into the Yedoma Ice Complex ice wedges (Fig. 3a). Milky white ice veins likely of Holocene origin were observed in the upper parts of two huge ice wedges of the Yedoma Ice Complex.

The Holocene cover deposits were radiocarbon dated to the early Holocene with mean ages of about 11.0 to 8.9 cal kyr b2k (Table 5).

\subsubsection{Generalized stratigraphic sequences}

The described cryolithological units and the respective ice wedges have been studied in three generalized stratigraphic sequences $\mathrm{A}$ to $\mathrm{C}$ (Fig. 2).

The first sequence $\mathrm{A}$ represents the stratigraphy of the eastern part of the study area (A in Fig. 2). It consists of Kuchchugui floodplain deposits of Unit I, Buchchagy Ice Complex (Unit II), and Krest Yuryakh thermokarst-lake de- 
posits (Unit III), discordantly overlain by Yedoma Ice Complex (Unit IV) and Holocene cover (Unit VIII).

The second sequence, $\mathrm{B}$, in the central part of the study area (B in Fig. 2) comprises Kuchchugui floodplain deposits (Unit I) covered by Buchchagy Ice Complex (Unit II) and Krest Yuryakh thermokarst-lake deposits (Unit III). The main part consists of Yedoma Ice Complex deposits (Unit IV) overlain by the Holocene cover (Unit VIII).

Sequence $\mathrm{C}$ in the western part of the study area (C in Fig. 2) is represented by about $10 \mathrm{~m}$ high thermokarst-basin outcrops and comprises Krest Yuryakh thermokarst-lake deposits (Unit III), covered by taberal Yedoma Ice Complex (Unit V) as well as late glacial to Holocene thermokarstlake (Unit VI) and thermokarst-basin palustrine deposits (Unit VII).

\subsection{Stable isotope composition of ground ice}

The basic parameters of the studied ice wedges of different units as well as their stable-isotope data are presented in Table 6 . The attribution of ice wedges to certain stratigraphic units is based on field observations and stable isotope data. Additionally, pore- and segregated-ice stable isotope data are also summarized in Table 6. Overall, both ice-wedge as well as pore- and segregated-ice stable-isotope data show a high variability over time.

\subsubsection{Unit I Kuchchugui floodplain deposits}

The composite wedges exhibit mean $\delta^{18} \mathrm{O}$ values of $-30.7 \%$ o for Oya IW1 ( $\delta \mathrm{D}$ : $-240.5 \%$ ) and $-28.2 \%$ for Oy7-03 IW4 ( $\delta \mathrm{D}:-225.6 \%$ ) with low internal variability (Fig. 4; Table 6). Their respective mean $d$ excess values were low $(4.8 \%$ and $0 \%$ ). The corresponding slopes (intercepts) in a $\delta^{18} \mathrm{O}-\delta \mathrm{D}$ bi-plot are 7.41 and $6.7(-13.23$ and -36.78$)$, respectively.

In the composite-wedge parts (Oy7-03 IW1+5), the intersected multi-stage ice wedges showed mean values of $-29.7 \%$ for $\delta^{18} \mathrm{O},-235.0 \%$ for $\delta \mathrm{D}$, and $2.3 \%$ or $d$ excess with a regression line of $\delta \mathrm{D}=8.68 \times \delta^{18} \mathrm{O}+22.46\left(r^{2}=\right.$ $0.98)$. The upper regular part showed the lowest $\delta^{18} \mathrm{O}$ and $\delta \mathrm{D}$ mean values $(-34.1$ and $-268.0 \%$, respectively) observed in all units at the Oyogos Yar Coast (Fig. 4; Table 6). The mean $d$ excess value is $4.9 \%$ and the co-isotopic regression line $\delta \mathrm{D}=8.74 \times \delta^{18} \mathrm{O}+29.99\left(r^{2}=0.93\right)$.

Pore- and segregated-ice stable-isotope values scatter between -29.8 and $-23.1 \%$ or $\delta^{18} \mathrm{O},-231.8$ and $-191.4 \%$ o for $\delta \mathrm{D}$, and -8.0 and $6.2 \%$ for $d$ excess (Fig. 4; Table 6). The regression line in a co-isotopic $\delta^{18} \mathrm{O}-\delta \mathrm{D}$ plot is $\delta \mathrm{D}=$ $6.24 \times \delta^{18} \mathrm{O}-48.31\left(r^{2}=0.99\right)$, quite similar to that of composite wedge Oy7-03 IW4.

\subsubsection{Unit II Buchchagy Ice Complex deposits}

One syngenetic ice wedge was assigned to the Buchchagy Ice Complex (Oy7-07 IW1). The mean stable-isotope values $(n=7)$ are $-33.1 \%$ or $\delta^{18} \mathrm{O},-258.3 \%$ for $\delta \mathrm{D}$, and $6.7 \%$ or $d$ excess with very little variability (Fig. 4; Table 6). The regression line in a $\delta^{18} \mathrm{O}-\delta \mathrm{D}$ bi-plot is $\delta \mathrm{D}=$ $6.96 \times \delta^{18} \mathrm{O}-27.89\left(r^{2}=0.98\right)$.

Pore- and segregated-ice stable-isotope values scatter between -29.8 and $-23.3 \%$ for $\delta^{18} \mathrm{O},-233.8$ and $-184.9 \%$ o for $\delta \mathrm{D}$, and -1.9 and $9.9 \%$ for $d$ excess (Fig. 4; Table 6). The regression line in a co-isotopic $\delta^{18} \mathrm{O}-\delta \mathrm{D}$ plot with $\delta \mathrm{D}=$ $6.89 \times \delta^{18} \mathrm{O}-26.83\left(r^{2}=0.98\right)$ is similar to the ice-wedge data.

\subsubsection{Unit IV Yedoma Ice Complex deposits}

In total, 10 ice wedges of the Yedoma Ice Complex were studied at different altitude levels from 1.5 to about $35 \mathrm{~m}$ a.s.l. Close to the ground surface at the top of the Yedoma Ice Complex as well as at the slope to the thermokarst basin, two ice wedges (Oy7-06 IW2 and Oy708 IW3) showed evidence of Holocene frost-cracking activity, i.e. Holocene ice veins. The respective samples, i.e. those with $\delta^{18} \mathrm{O}$ values higher than $-28.0 \%$ (maximum value of unaffected ice wedges of Unit IV and slightly lower than the minimum value $(-27.1 \%$ o $)$ of Holocene ice wedges in Unit VII), were accordingly assigned to Unit VIII (Holocene cover deposits) instead of Unit IV.

The overall mean stable isotope values of the Yedoma Ice Complex ice wedges are $-30.8 \%$ for $\delta^{18} \mathrm{O},-240.2 \%$ o for $\delta \mathrm{D}$, and $5.9 \%$ for $d$ excess with a regression line of $\delta \mathrm{D}=8.33 \times \delta^{18} \mathrm{O}+15.92\left(r^{2}=0.98\right)$. The mean values for single ice-wedge profiles vary between -32.8 and $-29.2 \%$ o for $\delta^{18} \mathrm{O},-258.3$ and $-227.6 \%$ for $\delta \mathrm{D}$, and 3.7 and $8.1 \%$ 。 for $d$ excess (Table 6, Fig. 4) without any clear altitudinal trend (Fig. 5).

The pore- and segregated-ice stable-isotope values exhibit an enormous scatter and vary between -34.5 and $-18.5 \%$ o for $\delta^{18} \mathrm{O},-253.9$ and $-150.5 \%$ for $\delta \mathrm{D}$, and -10.9 and $21.7 \%$ for $d$ excess (Table 6, Fig. 4). The co-isotopic regression line is $\delta \mathrm{D}=6.51 \times \delta^{18} \mathrm{O}-36.00\left(r^{2}=0.97\right)$. A substantial altitudinal variability shows a generally decreasing (increasing) trend in $\delta^{18} \mathrm{O}$ and $\delta \mathrm{D}$ ( $d$ excess) values from about $6 \mathrm{~m}$ a.s.l. to a pronounced minimum (maximum) around $20 \mathrm{~m}$ a.s.l. and again higher (lower) values above (Fig. 5).

\subsubsection{Unit VII palustrine deposits}

The ice-wedge stable-isotope samples from Unit VII can be assigned to four groups: (1) older, lower sections; (2) highresolution vertical profiles in the younger, upper section; (3) recent, i.e. central, parts of upper sections; and (4) modern ice veins, i.e. rejuvenation stages. The first two groups show 


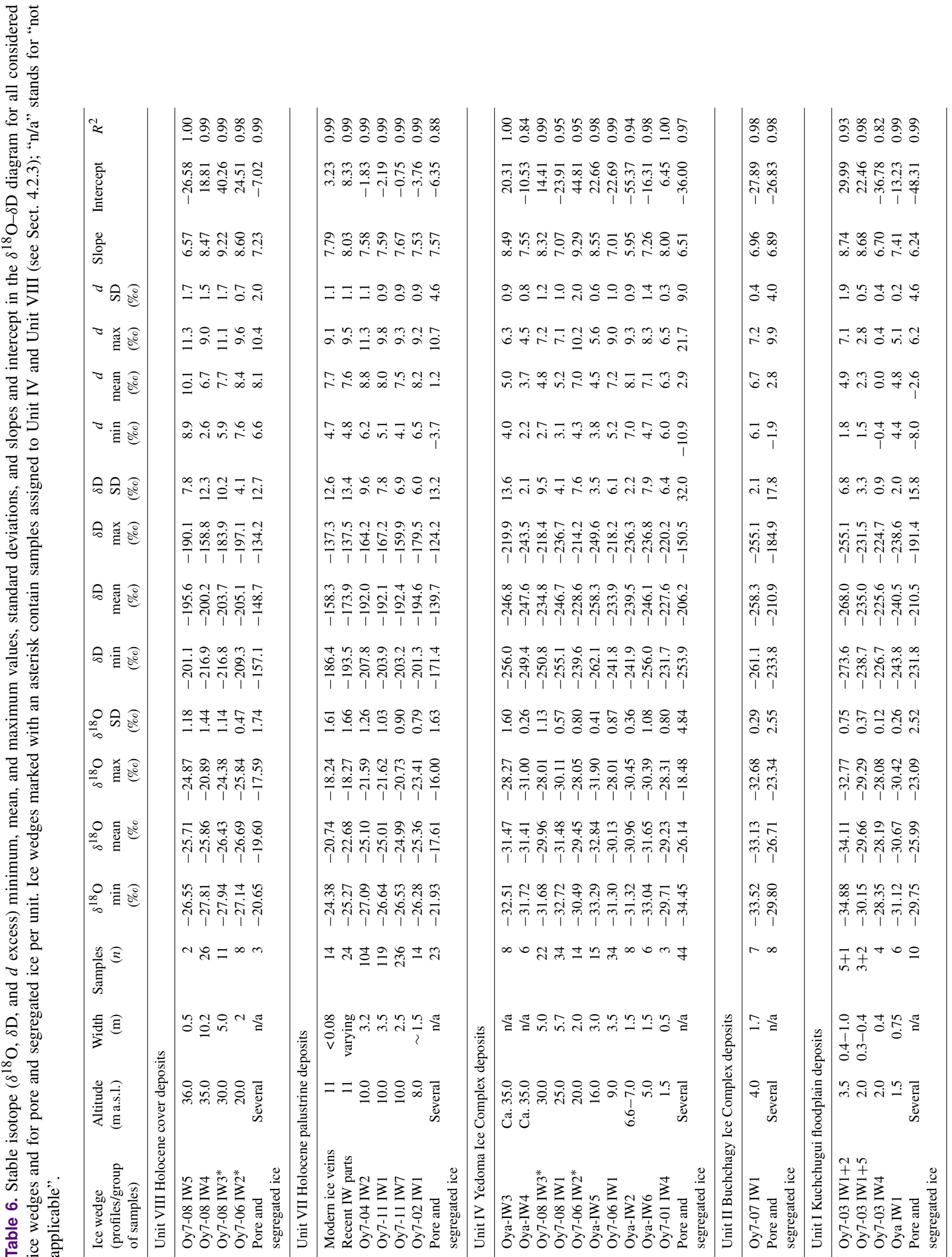



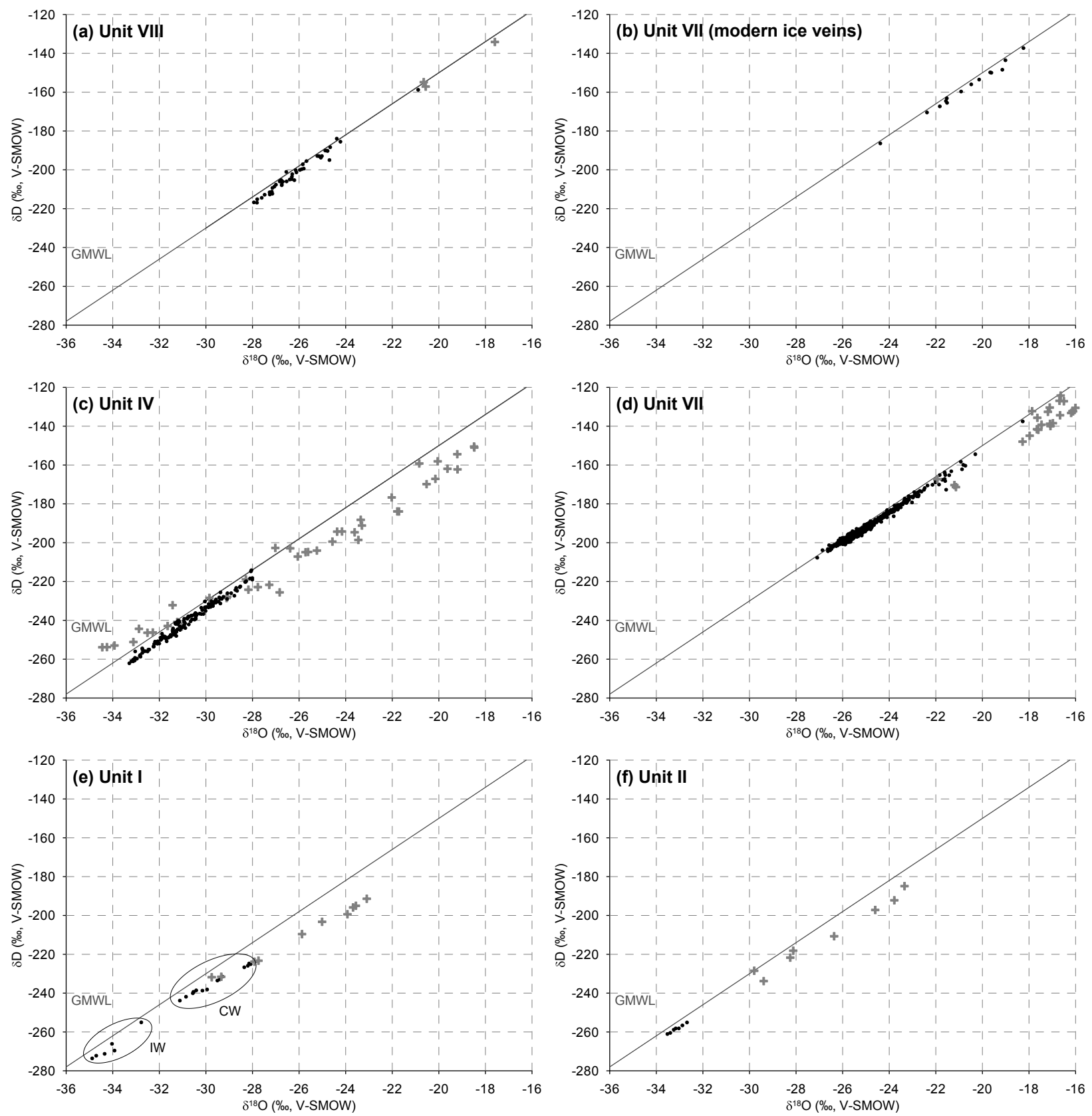

Figure 4. $\delta^{18} \mathrm{O}-\delta \mathrm{D}$ diagrams for ice-wedge and pore- and segregated-ice data assigned to the studied units. Black dots refer to ice-wedge data and grey crosses to data of pore and segregated ice. In panel (e) IW indicates ice-wedge samples and CW composite-wedge samples.

quite similar isotopic compositions, with mean values between -25.4 and $-25.0 \%$ or $\delta^{18} \mathrm{O},-194.6$ and $-192.0 \%$ o for $\delta \mathrm{D}$, and 7.5 and $8.8 \%$ for $d$ excess with co-isotopic slopes between 7.53 and 7.67 and intercepts between -3.76 and -0.75 (Table 6, Fig. 4). The recent ice-wedge parts exhibit more enriched isotopic compositions with mean values of $-22.7 \%$ of $\delta^{18} \mathrm{O},-173.9 \%$ for $\delta \mathrm{D}$, as well as $7.6 \%$ o for $d$ excess, whereas the modern ice veins show the most enriched mean values of all samples: $-20.7 \%$ for $\delta^{18} \mathrm{O}$, $-158.3 \%$ for $\delta \mathrm{D}$, and $7.7 \%$ for $d$ excess. The co-isotopic regression lines are with $\delta \mathrm{D}=8.03 \times \delta^{18} \mathrm{O}+8.33\left(r^{2}=\right.$ $0.99)$ and $\delta \mathrm{D}=7.79 \times \delta^{18} \mathrm{O}+3.23\left(r^{2}=0.99\right)$, close to the Global Meteoric Water Line (GMWL: $\delta \mathrm{D}=8 \times \delta^{18} \mathrm{O}+10$ ).

The pore- and segregated-ice stable-isotope values group between -21.9 and $-16.0 \%$ for $\delta^{18} \mathrm{O},-171.4$ and $-124.2 \%$ or $\delta \mathrm{D}$, and -3.7 and $10.7 \%$ for $d$ excess $(\mathrm{Ta}-$ ble 6). $\delta^{18} \mathrm{O}$ and $\delta \mathrm{D}$ build two clusters in the co-isotope plot (Fig. 4). The regression line is close to that of the ice wedges $\left(\delta \mathrm{D}=7.57 \times \delta^{18} \mathrm{O}-6.35\right)$ but with a weaker correlation $\left(r^{2}=0.88\right)$. 


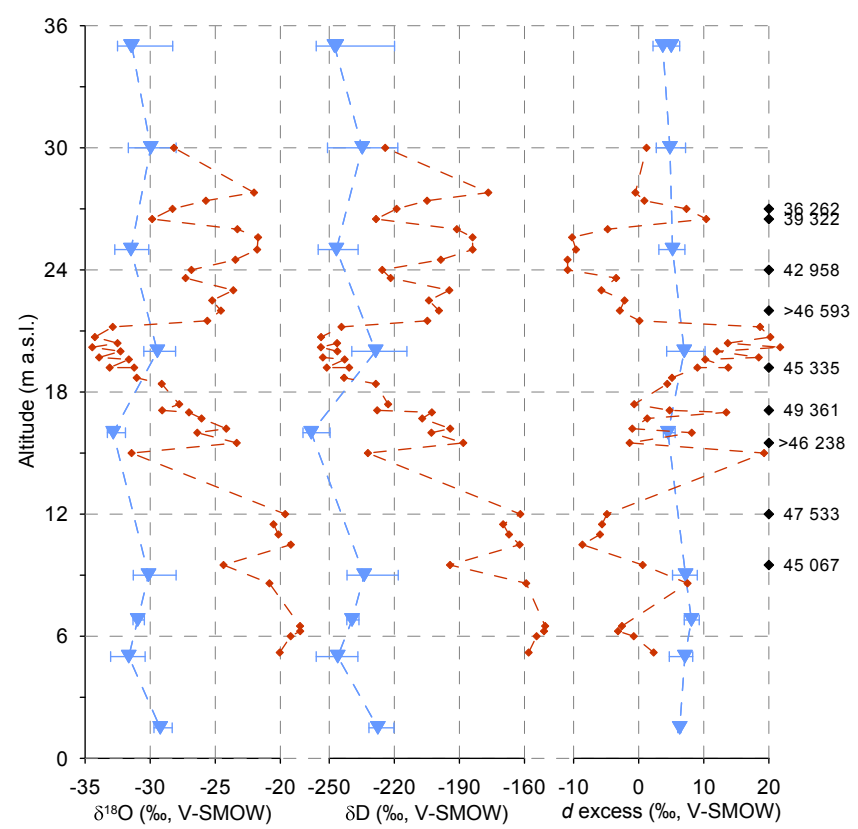

Figure 5. Single $\delta^{18} \mathrm{O}, \delta \mathrm{D}$, and $d$ excess data of pore and segregated ice (red dots) and $\delta^{18} \mathrm{O}, \delta \mathrm{D}$, and $d$ excess data (min, mean, max) of horizontal ice wedges profiles (blue triangles) of the Yedoma Ice Complex (Unit IV) plotted against altitude. Additionally given are radiocarbon ages (mean calibrated $\mathrm{yr} b 2 \mathrm{k}$; in two cases minimum ages) obtained from sediment samples. These ages do not necessarily reflect the age of the ice wedges, which are assumed to be younger.

\subsubsection{Unit VIII Holocene cover on top of the ice complex}

The Holocene-influenced ice-wedge parts of the Yedoma Ice Complex show relatively little isotope variations. Mean values vary between -26.7 and $-25.9 \%$ for $\delta^{18} \mathrm{O},-205.1$ and $-200.2 \%$ for $\delta \mathrm{D}$, and 6.7 and $8.4 \%$ for $d$ excess. The coisotopic regression slopes vary between 8.47 and 9.22 with intercepts between 18.81 and 40.26 (Table 6, Fig. 4). The two samples from a small ice wedge in the initial thermokarst depression show slightly more enriched values (mean $\delta^{18} \mathrm{O}$ : $-24.9 \%$; mean $\delta \mathrm{D}:-195.6 \%$; mean $d$ excess: $10.1 \%$ ).

The pore- and segregated-ice stable-isotope data are more enriched and spread between -20.7 and $-17.6 \%$ for $\delta^{18} \mathrm{O}$, -157.1 and $-134.2 \%$ for $\delta \mathrm{D}$, and 6.6 and $10.4 \%$ for $d$ excess. The regression line accounts for $\delta \mathrm{D}=7.23 \times$ $\delta^{18} \mathrm{O}-7.02\left(r^{2}=0.99\right)$.

\section{Discussion}

\subsection{Chronostratigraphy and landscape development of the Oyogos Yar mainland}

We identified 8 cryostratigraphic units at the Oyogos Yar coast, whereas 12 were found at the opposite southern coast of Bol'shoy Lyakhovsky Island (Table 1). They basically represent three main landscape types which have undergone dif- ferent permafrost aggradation and degradation patterns that varied over time and in space: ice complex deposits, flood plain deposits, and thermokarst-lake and thermokarst-basin palustrine deposits. Hence, often a clear attribution of deposits and ice wedges to distinct units and their relation to each other is challenging, in particular for pre-Yedoma Ice Complex units which cannot be dated by the radiocarbon method.

At the Oyogos Yar coast we did not find deposits of the Yukagir Ice Complex $\left({ }^{230} \mathrm{Th} / \mathrm{U}\right.$ dated to $\left.200.9 \pm 3.4 \mathrm{kyr}\right)$ and the Zimov'e layer (IRSL-dated to $134 \pm 22 \mathrm{kyr}$ ) both known from Bol'shoy Lyakhovsky Island (Table 1). Hence, at our study site Kuchchugui floodplain deposits represent the oldest unit (Unit I). The obtained IRSL age of $112.5 \pm 9.6 \mathrm{kyr}$ of Unit I in sequence B (Fig. 2) is older by about 10 kyr than the respective ages of Kuchchugui deposits from Bol'shoy Lyakhovsky Island but falls within the error range of the previous age determinations (Table 1). The latter were obtained from Kuchchugui taberal deposits below an ice-wedge cast assigned to the last interglacial. Hence, they may be influenced by thaw and refreeze during subsequent thermokarst-lake development and may therefore represent rather minimum ages (Andreev et al., 2004).

The radiocarbon ages of $>44.5$ and $45.2 \mathrm{cal} \mathrm{kyr} \mathrm{b2k}$ (Table 4) point to a much younger age of Unit I in the eastern sequence A (Fig. 2) but are close to the limit of the radiocarbon method. The stratigraphic position of Unit I below deposits of the Buchchagy Ice Complex of Unit II supports the age information obtained from IRSL dating, which is why we discard the radiocarbon age.To exclude a possible attribution of Unit I in the eastern part of the study region (sequence A) to the Zyryanian stadial known from Bol'shoy Lyakhovsky Island (Table 1), additional age control is greatly needed, if possible also using other approaches, e.g. uranium decay series in ground ice (Ewing et al., 2015). The Zyryanian at Bol'shoy Lyakhovsky Island shows similar sedimentary characteristics, pointing to floodplain deposits (Andreev et al., 2004), but contains toes of Yedoma Ice Complex ice wedges instead of the small truncated composite wedges found for Unit I at Oyogos Yar. Kuchchugui ice wedges of Unit I at Oyogos Yar are smaller and have isotopic values that are less depleted compared to ice wedges on Bol'shoy Lyakhovsky Island (see Sect. 5.2). The ${ }^{36} \mathrm{Cl} / \mathrm{Cl}^{-}$ages of $98 \pm 31$ and $68 \pm 31 \mathrm{kyr}$ (Blinov et al., 2009) for ice wedges Oy7-03 IW1 and IW2 cannot definitively resolve the attribution to a stratigraphic unit but rather confirm the IRSL age for Unit I in section A. We therefore, interpret Unit I in section A as floodplain deposits of the early MIS5 with subsequent ice complex formation.

The Buchchagy Ice Complex (Unit II) is known from both sides of the Dmitry Laptev Strait and represents ice complex formation of MIS5 age. It developed above the Kuchchugui floodplain deposits from $126+16 /-13$ and $117+19 /-14 \mathrm{kyr}$ to $93 \pm 5$ and $89 \pm 5 \mathrm{kyr}$ as deduced by ${ }^{230} \mathrm{Th} / \mathrm{U}$ dating of two enclosing peat horizons on Bol'shoy 
Lyakhovsky Island (Wetterich et al., 2016). Its syngenetic ice wedges penetrate into the underlying Kuchchugui floodplain deposits. Given the age of the Kuchchugui deposits and the rather large uncertainty range of the ${ }^{230} \mathrm{Th} / \mathrm{U}$ dating (in particular for the lower peat), the Buchchagy Ice Complex development likely took place in MIS5d-5b between about 110 and 90 kyr. The cryostratigraphic relation of Unit II of Oyogos Yar to Bol'shoy Lyakhovsky Island is additionally confirmed by the very similar stable-isotope composition of ice-wedge samples from both locations (see Sect. 5.2).

The Krest Yuryakh thermokarst-lake and thermokarstbasin palustrine deposits (Unit III) indicate warm temperatures, at least in the summer season. These deposits filled ice-wedge casts in taberal deposits; they were encountered within wide thermokarst basins which had developed in the degraded ice-rich Buchchagy Ice Complex of Unit II and are therefore younger. In this paper we present the first direct age determination for the Krest Yuryakh Suite at the Dmitry Laptev Strait derived from deposits within an icewedge cast. The IRSL for Unit III $(102.4 \pm 9.7 \mathrm{kyr})$ points to a MIS5c origin rather than MIS5e (Eemian) as suggested previously (Wetterich et al., 2009; Kienast et al., 2011). The warm summer climate conditions inferred from the presence of extensive thermokarst lakes, however, fit in well with a maximum in modelled summer temperatures of around $105 \mathrm{kyrb} 2 \mathrm{k}$ (Andreev et al., 2011; Ganopolski and Calov, 2011) (Fig. 7). It further narrows the duration of the Buchchagy Ice Complex development. The radiocarbon age

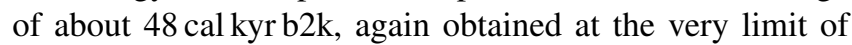
the radiocarbon method, might point to a distinctly younger formation of Unit III. However, as it clearly contradicts the IRSL age, we assume relocation of the dated material and therefore discard this age. Given the dating uncertainties and temporal overlaps for Units I to III, an absolute chronology is still challenging. Moreover, a temporal coexistence of ice complex accumulation plains, thermokarst basins, and floodplains in the same region during MIS5 cannot be excluded but is considered to be unlikely.

In contrast to Bol'shoy Lyakhovsky Island, there is neither dating nor sedimentary evidence of floodplains of the Zyryanian stadial (MIS4) at Oyogos Yar (Table 1), even though the presence of such Zyryanian stadial deposits in the eastern section A cannot be ruled out and requires age control as part of future studies.

The Yedoma Ice Complex (Unit IV) started forming at Oyogos Yar from at least $50 \mathrm{kyr}$ b2k, confirming earlier findings (Gravis, 1978; Kaplina and Lozhkin, 1984; Tomirdiaro, 1984; Nagaoka et al., 1995). Radiocarbon ages from Bol'shoy Lyakhovsky Island indicate even earlier ice complex formation since about $60 \mathrm{cal} \mathrm{kyrb2k}$ (Table 1) (Wetterich et al., 2014). Even though the youngest age from Unit IV at Oyogos Yar is dated to 36.3 cal kyr b2k (Table 4) a longer Yedoma Ice Complex formation can be assumed as indicated by Bol'shoy Lyakhovsky Island, where ages of 33.5 to 32.5 cal kyr 2 bk have been found for the Molotkov inter- stadial stratum of the Yedoma Ice Complex (Andreev et al., 2009; Wetterich et al., 2014) (Table 1). It remains unclear whether the Yedoma Ice Complex formation at Oyogos Yar continued further until the Sartan stadial (or even until the end of the Pleistocene as is known from Cape Mamontov Klyk (Schirrmeister et al., 2008a) and Bykovsky Peninsula (Schirrmeister et al., 2002b)) or whether the accumulation regime has changed. On Bol'shoy Lyakhovsky Island the prevailing Yedoma Ice Complex formation moved from plain to erosional landforms such as river valleys where the Sartan stadial stratum of the Yedoma Ice Complex was formed at least between about 30 and $26.7 \mathrm{cal} \mathrm{kyr} \mathrm{b2k}$ (Wetterich et al., 2011). At Oyogos Yar potential equivalent ice complex deposits in river valleys have not been found along the studied coastline section but may exist further east in the valley of the Kondrat'eva River.

Consequently, it is not possible to estimate whether there was substantial permafrost degradation on the top of the Oyogos Yar Yedoma Ice Complex during the postglacial warming and the duration of the potential erosional gap. The Holocene cover (Unit VIII) has been developed since $11 \mathrm{cal} \mathrm{kyr} \mathrm{b2k} \mathrm{ac-}$ cording to our data, which mirror Bol'shoy Lyakhovsky Island conditions (Andreev et al., 2009; Wetterich et al., 2014).

Dated thermokarst-lake deposits of Unit VI prove widespread permafrost degradation, i.e. the development of vast thermokarst basins during the last deglaciation.

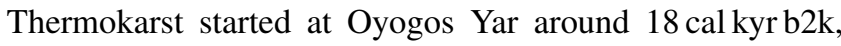
about $3 \mathrm{kyr}$ earlier than reported for Bol'shoy Lyakhovsky Island (Andreev et al., 2009; Wetterich et al., 2009). The lacustrine phase (Unit VI) of the studied Oyogos Yar thermokarstbasin development ended around $13 \mathrm{cal} \mathrm{kyr} \mathrm{b2k}$. This confirms results of earlier studies (Gravis, 1978; Kaplina and Lozhkin, 1984; Tomirdiaro, 1984; Nagaoka et al., 1995). In contrast, on Bol'shoy Lyakhovsky Island the lacustrine phase of the studied thermokarst basins ended only around 8 cal kyr b2k (Andreev et al., 2009; Wetterich et al., 2009). However, thermokarst development depends on manifold factors such as (micro-)climate, relief, substrate, ice content, and drainage. Hence, these deviations are regarded as minor given the fact that they fit into the general temporal pattern of thermokarst formation during the last deglaciation (Walter et al., 2007).

The palustrine phase (Unit VII) covers the entire Holocene, includes the distinctive peat horizon (about $9.3 \mathrm{kyr} b 2 \mathrm{k}$ ), and continues until today. The youngest radiocarbon age of the palustrine deposits $(3.6 \mathrm{kyr} b 2 \mathrm{k})$ and the series of radiocarbon ages of actively growing ice wedges covering the last two millennia (Table 5) (Opel et al., 2017a) as well as the shape of the ice wedges point to a predominantly lateral ice-wedge growth in the late Holocene. This indicates rather stable surfaces in the thermokarst basin with low accumulation rates. 


\subsection{Regional palaeoclimate deduced from ground ice and its stable-isotope compositions}

For all Oyogos Yar units the mean stable-isotope compositions of ice wedges are more depleted than those of pore and segregated ice. Mean $\delta^{18} \mathrm{O}$ values of ice wedges are between about 2 and $8 \%$ and mean $\delta \mathrm{D}$ values between about 15 and $58 \%$ lower than the corresponding mean values of pore and segregated ice (Fig. 4). Except for two ice wedges of Unit VIII, mean ice-wedge $d$ excess values are higher by about 1 to $7 \%$ o than the respective values of pore and segregated ice. The slopes in a $\delta^{18} \mathrm{O}-\delta \mathrm{D}$ diagram are in most cases lower for pore and segregated ice than for ice wedges (Table 6). This reflects the differences in ice genesis involving different water sources and fractionation processes. Whereas ice-wedge stable isotopes reflect a direct winter climate signal, the contribution of summer precipitation as well as evaporation effects may be responsible for the more enriched mean stable isotope values of pore and segregated ice (Meyer et al., 2002a; Schwamborn et al., 2006). On the other hand, freezing processes within the seasonally thawed active layer would both enrich and deplete stable-isotope values as discussed below. Hence, the climatic interpretation of stable isotopes in particular pore- and segregated-ice samples is challenging due to the partial overprinting of the original meteoric signal by secondary fractionation processes associated with consecutive freeze-thaw cycles within the active layer. The degree of overprinting may depend heavily on the specific environmental conditions during final ice formation (e.g. composition of soil moisture in terms of different water sources, climate conditions, freezing direction, and velocity). However, mean stable-isotope data of pore and segregated ice may indicate generally colder climate conditions for the formation of Units I, II, and IV during distinct periods of the last interglacial and glacial and significantly warmer conditions for the formation of Units VII and VIII during the Holocene (Fig. 4; Table 6).

The enormous scatter of stable isotopes of pore and segregated ice within the Yedoma Ice Complex (Unit IV) (Fig. 5) leads to the interpretation that it does reflect mainly secondary fractionation processes rather than climate conditions. In particular the $\delta^{18} \mathrm{O}$ and $\delta \mathrm{D}$ minimum with a corresponding $d$ excess maximum around $20 \mathrm{~m}$ a.s.l., where poreand segregated-ice $\delta^{18} \mathrm{O}$ and $\delta \mathrm{D}$ values drop even below icewedge $\delta^{18} \mathrm{O}$ and $\delta \mathrm{D}$ values, indicates a substantial contribution of non-climate-related secondary fractionation processes (Fig. 5). Besides changing proportions of different moisture sources (summer and winter precipitation, meltwater) and evaporation from the active layer and polygonal ponds (leading to a heavier isotopic composition of the remaining water), in particular numerous freeze-thaw cycles with moisture segregation are assumed to control the soil moisture's stableisotope composition before it enters a perennially frozen state. During freezing, soil moisture migrates to the freezing front. This process is accompanied by kinetic isotope frac- tionation, where the first ice lenses exhibit a heavier isotopic composition than the remaining soil moisture and in particular the ice formed last. Hence, the $\delta^{18} \mathrm{O}$ and $\delta \mathrm{D}$ decrease from 15 to $21 \mathrm{~m}$ a.s.l. is most likely related to persistent sediment freezing leading to very low $\delta^{18} \mathrm{O}$ and $\delta \mathrm{D}$ as well as high $d$ excess values in the last freezing stage.

In contrast, more detailed and constrained climate variability is traceable from ice-wedge stable-isotope values, in particular when a reliable age control is available. This is indicated by ice-wedge co-isotopic slopes closer to the GMWL (Table 6) and recent precipitation (Meyer et al., 2002b; Opel et al., 2011). Ice-wedge stable isotopes allow us to detect winter temperature variability on different timescales from the glacial-interglacial scale to the intra-unit scale (such as within Unit IV Yedoma Ice Complex) up to the centennial scale (such as within an ice wedge).

In the following we discuss the ice-wedge stable-isotope data from Oyogos Yar obtained within this study. In a first step we relate our data to those from Bol'shoy Lyakhovsky Island published previously (Meyer et al., 2002b; Wetterich et al., 2009, 2011, 2014, 2016) to enhance the palaeoclimatic understanding for the entire Dmitry Laptev Strait region (Fig. 6). However, one has to keep in mind that apart from a few ice wedges in Units IV (only Bol'shoy Lyakhovsky) and VII (Oyogos Yar and Bol'shoy Lyakhovsky), all ice wedges are dated only indirectly by age determinations of host sediments. Due to the downward transfer of snowmelt and corresponding stable isotope signatures into the frost cracks, which are several metres deep, ice wedges are always younger than host sediments at the exact same altitude. It is so far not possible to determine the corresponding age offsets between host sediments and studied syngenetic ice wedges for different units. Depending on deposition rates, estimated age offsets of a few hundred to a few thousand years seem to be most reasonable to us.

For our climate interpretation we use a tentative classification of mean ice-wedge $\delta^{18} \mathrm{O}$ values with six classes (extremely cold: -38 to $-35 \%$; very cold: -35 to $-32 \%$; cold: -32 to $-29 \%$; moderate -29 to $-26 \%$; warm: -26 to $-23 \% o^{\prime}$; very warm: -23 to $-20 \%$ ). This classification uses roughly the Last Glacial Maximum and modern climate conditions as endmembers.

The oldest ice wedges at the Dmitry Laptev Strait are from the Yukagir Ice Complex on Bol'shoy Lyakhovsky Island, dated to $200.9 \pm 3.4 \mathrm{kyr}$ (Table 1). The formation of ice complex ice wedges most likely occurred in stable climate and accumulation conditions. Meyer et al. (2002b) reported mean stable-isotope values of around $-32 \%$ for $\delta^{18} \mathrm{O}$ and around $-250 \%$ o for $\delta \mathrm{D}$ (Fig. 6). The inferred cold to very cold winter climate conditions indicate strong seasonal differences for the late MIS7 with warm and wet summers as reconstructed from biological proxies in host sediments (Andreev et al., 2004).

The occurrence of composite wedges in Kuchchugui floodplain deposits (Unit I) at Oyogos Yar points to a high- 

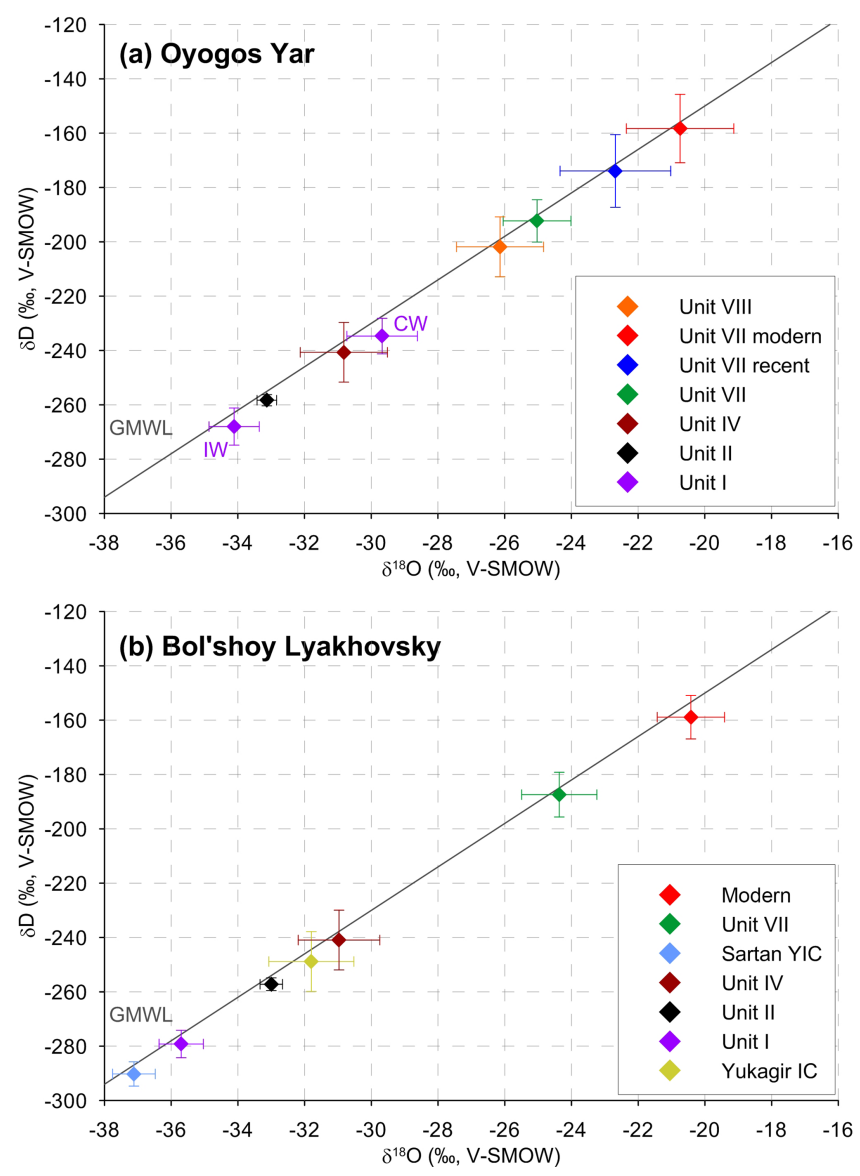

Figure 6. $\delta^{18} \mathrm{O}-\delta \mathrm{D}$ diagrams for ice-wedge data of the different units from Oyogos Yar (this study) compared to that from Bol'shoy Lyakhovsky Island (Meyer et al., 2002b; Wetterich et al., 2009, $2011,2014,2016)$. Shown are mean $\delta^{18} \mathrm{O}$ and $\delta \mathrm{D}$ values and respective standard deviations. IW indicates ice-wedge samples and CW composite-wedge samples.

accumulation regime that delivers sufficient material (e.g. wind-blown sand) to cause the high sediment fraction in these composite wedges. The latter is supported by the fact that the studied composite wedges (Oy7-03 IW4 and Oya IW1) are buried and truncated (Fig. 3f). Their convex thaw surfaces indicate a deepening of the active layer or a local water body that leads to a melting of the composite wedges' surface before deposition of new sediments. Their mean $\delta^{18} \mathrm{O}$ $(-28.2$ and $-30.7 \% o)$ and $\delta \mathrm{D}(-227$ and $-244 \%$ ) values point to moderate to cold winter temperatures during formation. However, given the little widths of the composite wedges and their high sediment content, the low internal variability, low $d$ excess values and low slopes may indicate different levels of isotopic exchanges between ice veins, sediment veins, and host sediments (Meyer et al., 2002a, 2010a). This is in particular likely for Oy7-03 IW4, which additionally shows a co-isotopic regression similar to that of corresponding pore and segregated ice (Table 6). Hence, we exclude the composite-wedge data from our palaeoclimatic interpretation. Interestingly, composite wedges Oy703 IW $1+5$ show similar regression lines as the intersected ice wedges Oy7-03 IW1+2 they pass into, but with distinctly enriched mean isotope values $\left(\delta^{18} \mathrm{O}:-29.7 \%\right.$; $\delta \mathrm{D}:-235 \%$; compared to $\delta^{18} \mathrm{O}:-34.1 \%$; $\delta \mathrm{D}:-268 \%$ ). Whereas the first fit into the described composite-wedge pattern well, the latter represents the minimum isotope values found at Oyogos Yar and indicate very cold winter climate during the early stage of ice-wedge formation in the Kuchchugui Unit I.

Even more severe climate conditions can be inferred from two Kuchchugui ice wedges on Bol'shoy Lyakhovsky Island. Mean stable isotope values of about $-35.5 \%$ for $\delta^{18} \mathrm{O}$ and $-280 \%$ for $\delta$ D (Fig. 6) indicate extremely cold winter temperatures (Meyer et al., 2002b). As pollen-based reconstructions point to relatively cold summer temperatures (Andreev et al., 2011), generally cold climate conditions can be concluded for this period, attributed to the MIS5 stadial.

The existence of the Buchchagy Ice Complex (Unit II) indicates cold-stage climate conditions during its formation on both sides of the Dmitry Laptev Strait. Very cold and stable winter climate conditions during ice-wedge formation are confirmed by ice-wedge $\delta^{18} \mathrm{O}$ and $\delta \mathrm{D}$ values (means -33 and $-258 \%$, respectively), which are slightly lower than those of the Yukagir ice wedges. The isotopic composition is nearly identical on both sides of the Dmitry Laptev Strait (Fig. 6) and underlines the stratigraphic correlation. Pollen-based reconstructions from host sediments indicate cool summer temperatures (Wetterich et al., 2016) and clearly point to stadial conditions with a generally colder climate in MIS5d.

The thick deposits of the Yedoma Ice Complex (Unit IV) with their huge ice wedges formed under long-term coldstage conditions during MIS3 (Molotkov interstadial stratum) from about 60 to about $32 \mathrm{cal} \mathrm{kyr} \mathrm{b2k}$. Mean $\delta^{18} \mathrm{O}$ and $\delta \mathrm{D}$ values of -31 and $-240 \%$, respectively, generally confirm cold winter temperatures during ice-wedge formation but indicate slightly warmer temperatures than those of Yukagir and Buchchagy times (Fig. 6). The variability in stableisotope values with altitude in this unit indicates changing conditions from very cold to moderate winter temperatures (Fig. 5). Similar variations have been observed in corresponding Yedoma Ice Complex ice wedges from Bol'shoy Lyakhovsky Island (Meyer et al., 2002b; Wetterich et al., 2014). However, due to age reversals in the dated sediment profiles (Fig. 5) (Schirrmeister et al., 2011b), it is not possible to attribute single ice-wedge profiles to distinct time periods. It is noteworthy that the ice-wedge profiles close to the top of Unit IV exhibit more depleted isotope compositions likely pointing to climate cooling towards the transition to MIS2.

The Sartan stadial stratum of the Yedoma Ice Complex on Bol'shoy Lyakhovsky Island formed at least between about 30 and $26.7 \mathrm{cal} \mathrm{kyrb2k}$ (Table 1) and exhibits the lowest stable-isotope values (mean $\delta^{18} \mathrm{O}$ of $-37 \%$; mean $\delta \mathrm{D}$ of $-290 \%$ ) (Fig. 6) found in ice wedges of the Dmitry Laptev Strait. They indicate extremely cold winter temperatures dur- 
ing the Last Glacial Maximum. A generally cold climate is furthermore confirmed by pollen-based temperature reconstruction from the host sediments (Wetterich et al., 2011).

Significantly enriched stable-isotope values were found in Holocene Oyogos Yar ice wedges in both cover deposits of the Yedoma Ice Complex (Unit VIII) and palustrine sediments of thermokarst basins (Unit VII) (Fig. 6). Mean $\delta^{18} \mathrm{O}(\delta \mathrm{D})$ values of about $-26 \%$ o $(-200 \%$ o and $-25 \%$ o $(-190 \%$ ) point to warm interglacial winter temperatures during ice-wedge formation. Similar mean values $\left(\delta^{18} \mathrm{O}\right.$ : $-24.5 \%$; $\delta \mathrm{D}:-187 \%$ ) were obtained from corresponding Holocene ice wedges on Bol'shoy Lyakhovsky Island (Meyer et al., 2002b; Wetterich et al., 2009). Distinctly warmer summer temperatures were also derived from pollen-based reconstructions, which, however, indicate a gradual cooling since the early Holocene (Andreev et al., 2009).

The warming from the last glacial to the Holocene is also accompanied by a slight increase (about $2 \%$ for Oyogos Yar; about $1 \%$ o for Bol'shoy Lyakhovsky Island) in mean $d$ excess values (Table 6). This likely indicates only minor changes in the moisture generation and transport patterns and/or seasonality of precipitation between the Pleistocene and Holocene.

Whereas no dating results for ice wedges from the cover deposits exist, radiocarbon ages from ice wedges of thermokarst-basin palustrine deposits on both sides of the Dmitry Laptev Strait indicate that the derived temperature information can be attributed mainly to the last two millennia. It is even possible to go into more detail. The recent parts of actively growing ice wedges at Oyogos Yar exhibit more enriched mean $\delta^{18} \mathrm{O}(\delta \mathrm{D})$ values of about $-23 \%$ ( $(-175 \%$ ). The highest $\delta^{18} \mathrm{O}(\delta \mathrm{D})$ values of about $-20.5 \%$ ( $(-160 \%$ ) on Oyogos Yar (Opel et al., 2017a) and Bol'shoy Lyakhovsky Island (Meyer et al., 2002b) were determined for modern ice veins, i.e. the youngest, actively growing ice wedges (rejuvenation stages). They represent the warmest winter temperatures of all reflected in ice-wedge stable isotopes from the Dmitry Laptev Strait (Fig. 6).

\subsection{Relation of ice-wedge palaeoclimate information to large-scale climate dynamics}

The present ice-wedge stable-isotope record of the Dmitry Laptev Strait is based on new data from Oyogos Yar and earlier data from Bol'shoy Lyakhovsky Island. It contains ice-wedge isotopes from seven stratigraphic units and covers roughly $200 \mathrm{kyr}$ (Table 1, Fig. 6). Other regional icewedge-based reconstructions such as those from Cape Mamontov Klyk (Boereboom et al., 2013), the Lena River delta (Wetterich et al., 2008), Bykovsky Peninsula (Meyer et al., 2002a), or Duvanny Yar at the Kolyma River (Vasil'chuk et al., 2001) only date back to MIS3 or MIS4 and/or contain only single stratigraphic units (Streletskaya et al., 2015). Therefore, we additionally compare our data to the continuous NGRIP ice-core $\delta^{18} \mathrm{O}$ record from Greenland (North Greenland Ice Core Project members, 2004) with age scale
GICC05modelext (Wolff et al., 2010) and climate-model output (Fig. 7). For the latter we use mean summer (JJA) and (extended) winter (DJFMAM, the cold period of the year, likely covered by ice-wedge stable isotopes) temperatures for the Laptev Sea region (centred at about $70^{\circ} \mathrm{N}, 120^{\circ} \mathrm{E}$ ) from the Earth system model of intermediate complexity CLIMBER-2 (Petoukhov et al., 2000) driven by orbital forcing and greenhouse gas concentrations (Ganopolski and Calov, 2011). When comparing these different datasets, we are aware that the stable-isotope datasets, i.e. our ice-wedge record and the Greenland ice-core record, are constrained by different seasonalities and different climate regimes and exhibit a different temporal resolution. Therefore, linking distinct high-amplitude events may be questionable. Furthermore, the age uncertainties in our record are comparably large and may be sufficient in several cased to bring the data into accord with the modelled temperatures.

The cold to very cold temperatures of Yukagir Ice Complex ice wedges inferred from stable-isotope values (age about $200 \mathrm{kyr}$ b2k) do not fit in with the modelled warm winter temperatures of this period. In contrast, warm summer climate conditions inferred from pollen (Andreev et al., 2004) confirm modelled summer temperatures. Considering an age offset between ice wedges and the dated peat horizon, it is likely that the ice wedges are younger and correspond to decreasing modelled winter temperatures between 200 and 180 kyr b2k (Fig. 7).

The very cold to extremely cold temperatures reflected in stable isotopes of Kuchchugui ice wedges (Unit 1, dated to about 110 to $100 \mathrm{kyr}$ 2k) do not fit in with the modelled winter temperatures but correspond to a minimum in winter (i.e. NDJFAM (Meyer et al., 2015)) insolation around 100 kyr b2k (Laskar et al., 2004) (Fig. 7). Modelled cold winter periods were either earlier (around $130 \mathrm{kyrb} 2 \mathrm{k}$ ) or later (around $90 \mathrm{kyrb2k}$ ) both accompanied by cold summer temperatures (Fig. 7) as also inferred from Kuchchugui pollen (Andreev et al., 2011). In contrast, the NGRIP ice-core record shows a colder period around $110 \mathrm{kyr} b 2 \mathrm{k}$ that might correspond to the very low ice-wedge $\delta^{18} \mathrm{O}$ and $\delta \mathrm{D}$ values of the Kuchchugui ice wedges in Unit I. Considering a potential Zyranian age interpretation for the corresponding floodplain deposits in sequence A (see Sect. 5.1), even the very cold MIS4 stadial (around $65 \mathrm{kyr}$ b2k) seems to be a possible interpretation.

The inferred very cold winter temperatures of the Buchchagy Ice Complex ice wedges also do not correspond to a corresponding cold period in modelled winter temperatures but may fit in with the cold period around $110 \mathrm{kyr}$ 22k seen in the NGRIP ice core. A younger age can be ruled out as the Krest Yuryakh warm period with enhanced thermokarst processes including melting of ice wedges attributed to the Buchagy Ice Complex is centred about 102 kyr b2k (MIS5c).

All in all, our data show a rather unexpected climate variability during MIS5. Surprisingly cold winter conditions dur- 


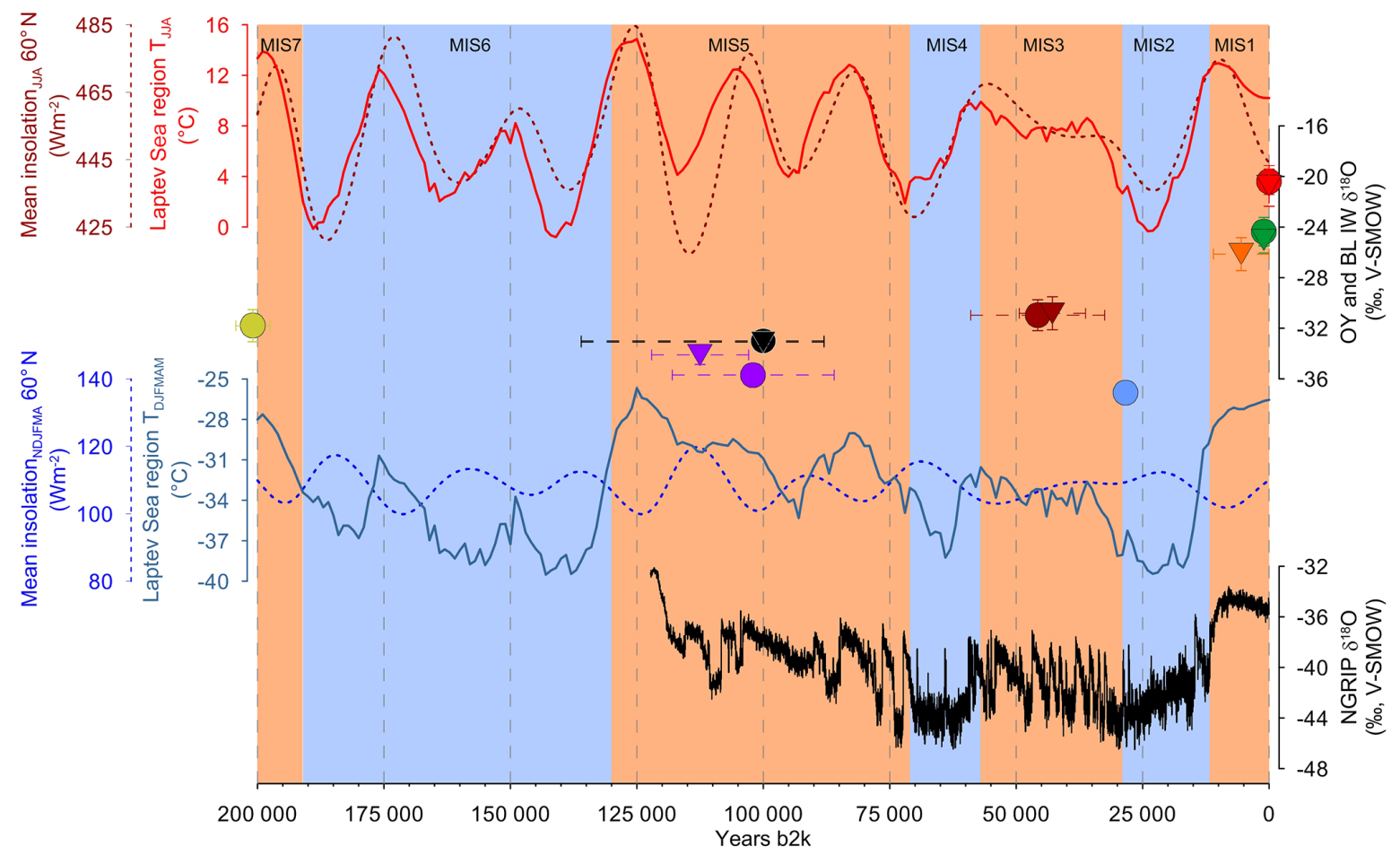

Figure 7. Mean $\delta^{18} \mathrm{O}$ data and standard deviations for the different units from Oyogos Yar (triangles) and Bol'shoy Lyakhovsky Island (circles) (interpreted age with maximum age ranges from Tables 1, 3, 4, and 5; colour coding corresponds to Fig. 6) compared to modelled mean summer and winter temperatures for the Laptev Sea region (Ganopolski and Calov, 2011), mean summer (JJA) and extended winter (NDJFAM) insolation at $60^{\circ} \mathrm{N}$ (Laskar et al., 2004), and the NGRIP $\delta^{18} \mathrm{O}$ ice-core record from Greenland (North Greenland Ice Core Project members, 2004; Wolff et al., 2010).

ing MIS5d were succeeded by the peak interglacial warming during MIS5c leading to widespread thermokarst formation with vast thermokarst lakes.

Both the NGRIP ice-core record and the modelled temperatures (summer and winter) show high-frequency climate fluctuations during MIS3. Even though not temporally resolvable, the altitudinal variability in ice-wedge isotopes at Oyogos Yar (Fig. 5) and Bol'shoy Lyakhovsky indicates that similar climate variations likely affected the Dmitry Laptev Strait region as well. Similar fluctuations within the same range of $\delta^{18} \mathrm{O}$ and $\delta \mathrm{D}$ values have also been reported for Cape Mamontov Klyk (Boereboom et al., 2013), the Bykovsky Peninsula (Meyer et al., 2002a), and Duvanny Yar (Vasil'chuk et al., 2001). A more stable MIS3 summer climate, even though with a distinct interstadial optimum around $40 \mathrm{cal} \mathrm{kyrb2k}$ was inferred from pollen data from Bol'shoy Lyakhovsky and other study sites in the Laptev Sea region (Wetterich et al., 2014).

The extremely cold winter temperatures reflected by icewedge stable isotopes of the Sartan stadial Yedoma Ice Complex on Bol'shoy Lyakhovsky correspond well to the Last Glacial Maximum cold period in the NGRIP ice-core record and the modelled temperatures (Fig. 7). Interestingly, such extremely depleted $\delta^{18} \mathrm{O}$ and $\delta \mathrm{D}$ values have not been found at any other study site in the Laptev Sea region, even though corresponding ice complex strata have been studied extensively (Wetterich et al., 2011).

The substantial warming from the last glacial to the Holocene as captured by modelled temperatures and the NGRIP record is also found in our Dmitry Laptev Strait record as well as other regional ice-wedge stable-isotope records such as Cape Mamontov Klyk (Boereboom et al., 2013), the Lena River delta (Wetterich et al., 2008), and the Bykovsky Peninsula (Meyer et al., 2002a). The detected $\delta^{18} \mathrm{O}$ difference of about $6 \%$ between the studied Yedoma Ice Complex (MIS3) and Holocene ice wedges corresponds well to the regional pattern. However, when comparing Last Glacial Maximum and Holocene ice wedges, $\delta^{18} \mathrm{O}$ values increased about twice as much (11-12\%o). This underlines the peculiarity of this cold event at the Dmitry Laptev Strait.

The slightly increasing mean $d$ excess values (about 2\%o for Oyogos Yar; about 1\%o for Bol'shoy Lyakhovsky Island), which go along with the last glacial to Holocene transition, are in line with observations at Cape Mamontov Klyk (Boereboom et al., 2013) and in the Lena River delta (Wetterich et al., 2008) and indicate rather constant moisture generation and transport pathways over this transition. In contrast, mean $d$ excess values at the Bykovsky Peninsula show an increase of about $10 \%$ (Meyer et al., 2002a) pointing to substantial changes in the local to regional moisture regime. 
The NGRIP record and the modelled summer temperatures show a cooling after the Northern Hemisphere early Holocene insolation maximum. In contrast, our ice-wedge data and the modelled winter temperatures verify a general Holocene winter warming trend with the highest temperatures today (Fig. 7), which is likely related to seasonal insolation and greenhouse gas forcing (Meyer et al., 2015; Opel et al., 2017a).

\section{Conclusions and outlook}

The present study summarizes comprehensive stable-isotope data from ice wedges interpreted as winter climate proxy from the Oyogos Yar mainland coast in addition to and in comparison to pre-existing data from Bol'shoy Lyakhovsky Island in the northeast Siberian Arctic covering the last 200 kyr. Seven distinct generations of ice wedge are distinguished, confirming coldest winter climate conditions during MIS5 and MIS2, warmest conditions during MIS1, and winter climate instability during MIS3. Since dating ice wedges directly is challenging and chronostratigraphic correlation to surrounding frozen deposits holds difficulties, which are even more complicated by different dating approaches beyond the radiocarbon limit (such as luminescence dating and radioisotope disequilibria dating), further method development is needed in ice-wedge dating and in understanding of the chronological relation between ice wedges and host sediments (i.e. age offsets). However, in the course of the present study, valuable geochronological data were obtained by the IRSL dating of the deposits of the Kuchchugui stratum to MIS5d (112.5 $\pm 9.6 \mathrm{kyr})$ and of the deposits of the Krest Yuryakh stratum to MIS5c (102.4 $\pm 9.7 \mathrm{kyr})$, formerly assigned to MIS5e. Comparing ice-wedge stable isotope data with climate-model output (CLIMBER-2) and Greenland ice-core records (NGRIP) revealed a high correspondence for MIS2 and MIS1. For older periods this is more difficult due to dating issues and rather low temporal resolution. In particular, high climate variability during MIS5 present in three units in the Oyogos Yar record is potentially controversial and requires further research to improve the application of ice-wedge stable isotopes as a winter climate proxy.

Data availability. The data presented in this paper are available at PANGAEA (https://doi.org/10.1594/PANGAEA.875146; Opel et al., 2017b).

Author contributions. Thomas Opel initiated and designed the present study and wrote the paper with contributions by the other co-authors. Thomas Opel, Alexander Y. Dereviagin, Hanno Meyer, Sebastian Wetterich, and Lutz Schirrmeister sampled and described ground ice and sediments. Hanno Meyer carried out stable-isotope analyses and supported interpretation. Margret C. Fuchs conducted IRSL dating and provided interpretation. Sebastian Wetterich and
Lutz Schirrmeister provided stratigraphic information and interpretation. All co-authors contributed to the final discussion of the results and interpretations obtained and have approved the final version of the paper.

Competing interests. The authors declare that they have no conflict of interest.

Acknowledgements. The study presented here is part of the Russian-German System Laptev Sea cooperative scientific effort. We thank our colleagues who helped during fieldwork and subsequent discussions as well as the staff of the AWI Potsdam stable isotope laboratory. We thank Andrey Ganopolski (PIK Potsdam, Germany) for providing climate-model output and Frank Günther for providing the detailed map in Fig. 1. Markus Richter (TU Dresden, Germany) and Ingrid Stein (TU Bergakademie Freiberg, Germany) supported IRSL dating. This study contributes to the project "Ice wedges as winter climate archives - towards highquality chronologies, advanced process understanding and new paleoclimate records" (Deutsche Forschungsgemeinschaft grant no. OP217/3-1). We thank Mikhail Kanevskiy, Trevor Porter, and Go Iwahana for thorough reviews and Julian Murton for valuable comments that greatly helped to improve the paper.

The article processing charges for this open-access publication were covered by a Research Centre of the Helmholtz Association.

Edited by: T. Cronin

Reviewed by: M. Kanevskiy, G. Iwahana, and T. J. Porter

\section{References}

Andreev, A. A., Grosse, G., Schirrmeister, L., Kuzmina, S. A., Novenko, E. Y., Bobrov, A. A., Tarasov, P. E., Ilyashuk, B. P., Kuznetsova, T. V., Krbetschek, M., Meyer, H., and Kunitsky, V. V.: Late Saalian and Eemian palaeoenvironmental history of the Bol'shoy Lyakhovsky Island (Laptev Sea Region, Arctic Siberia), Boreas, 33, 319-348, https://doi.org/10.1080/03009480410001974, 2004.

Andreev, A. A., Grosse, G., Schirrmeister, L., Kuznetsova, T. V., Kuzmina, S. A., Bobrov, A. A., Tarasov, P. E., Novenko, E. Y., Meyer, H., Derevyagin, A. Y., Kienast, F., Bryantseva, A., and Kunitsky, V. V.: Weichselian and Holocene palaeoenvironmental history of the Bol'shoy Lyakhovsky Island, New Siberian Archipelago, Arctic Siberia, Boreas, 38, 72-110, https://doi.org/10.1111/j.1502-3885.2008.00039.x, 2009.

Andreev, A. A., Schirrmeister, L., Tarasov, P. E., Ganopolski, A., Brovkin, V., Siegert, C., Wetterich, S., and Hubberten, H. W.: Vegetation and climate history in the Laptev Sea region (Arctic Siberia) during Late Quaternary inferred from pollen records, Quaternary Sci. Rev., 30, 2182-2199, https://doi.org/10.1016/j.quascirev.2010.12.026, 2011.

Arkhangelov, A., Mikhalev, D., and Nikolaev, V.: Rekonstruktsiya uslovii formirovaniya mnogoletnei merzloty i paleoklimatov Severnoi Evrazii (Reconstruction of formation conditions of 
permafrost and palaeoclimate of northern Eurasia), in: Razvitie oblasti mnnogoletnei merzloty i periglyatsial'noi zony Severnoi Evrazii i usloviya rasseleniya drevnego cheloveka (History of Permafrost Regions and Periglacial Zones of Northern Eurasia and Conditions of Old Human Settlement), edited by: Velichko, A., Arkhangelov, A., and Borisova, O., RAN Publishing, Moscow, Russia, 85-109, 1996.

Blinov, A., Alfimov, V., Beer, J., Gilichinsky, D., Schirrmeister, L., Kholodov, A., Nikolskiy, P., Opel, T., Tikhomirov, D., and Wetterich, S.: Ratio of $\mathrm{Cl}-36 / \mathrm{Cl}$ in ground ice of east Siberia and its application for chronometry, Geochem. Geophys. Geosyst., 10, Q0AA03, https://doi.org/10.1029/2009gc002548, 2009.

Boereboom, T., Samyn, D., Meyer, H., and Tison, J.-L.: Stable isotope and gas properties of two climatically contrasting (Pleistocene and Holocene) ice wedges from Cape Mamontov Klyk, Laptev Sea, northern Siberia, The Cryosphere, 7, 31-46, https://doi.org/10.5194/tc-7-31-2013, 2013.

Bøtter-Jensen, L., Andersen, C. E., Duller, G. A. T., and Murray, A. S.: Developments in radiation, stimulation and observation facilities in luminescence measurements, Radiat. Meas., 37, 535541, https://doi.org/10.1016/S1350-4487(03)00020-9, 2003.

Bronk Ramsey, C.: Bayesian Analysis of Radiocarbon Dates, Radiocarbon, 51, 337-360, 2009.

Bunge, A.: Bericht über den ferneren Gang der Expedition. Reise nach den Neusibirischen Inseln. Aufenthalt auf der Grossen Ljachof-Insel, in: Expedition zu den Neusibirischen Inseln und dem Jana-Lande (1885), edited by: Schrenk, L. V. and Maximovicz, C. J., Beitrage zur Kenntnis des russischen Reiches und der angrenzenden Länder Asiens, Kaiserliche Akademie der Wissenschaften, St. Petersburg, Russia, 231-284, 1887.

Dansgaard, W.: Stable isotopes in precipitation, Tellus, 16, 436468, 1964.

Dereviagin, A. Y., Chizhov, A., Meyer, H., Opel, T., Schirrmeister, L., and Wetterich, S.: Izotopny sostav teksturnyh l'dov poberez'ia moria Lapnevykh (Isotopic composition of texture ices, Laptev Sea Coast), Kriosfera Zemlii, 17, 27-34, 2013.

Dewald, A., Heinze, S., Jolie, J., Zilges, A., Dunai, T., Rethemeyer, J., Melles, M., Staubwasser, M., Kuczewski, B., Richter, J., Radtke, U., von Blanckenburg, F., and Klein, M.: CologneAMS, a dedicated center for accelerator mass spectrometry in Germany, Nucl. Instrum. Meth. B, 294, 18-23, https://doi.org/10.1016/j.nimb.2012.04.030, 2013.

Duller, G.: Analyst v4. 31.7 user manual, Aberystwyth Luminescence Research Laboratory, Aberystwyth University, Aberystwyth, UK, 77 pp., 2015.

Ewing, S. A., Paces, J. B., O’Donnell, J. A., Jorgenson, M. T., Kanevskiy, M. Z., Aiken, G. R., Shur, Y., Harden, J. W., and Striegl, R.: Uranium isotopes and dissolved organic carbon in loess permafrost: Modeling the age of ancient ice, Geochim. Cosmochim. Acta, 152, 143-165, https://doi.org/10.1016/j.gca.2014.11.008, 2015.

French, H. and Shur, Y.: The principles of cryostratigraphy, Earth-Sci. Rev., 101, 190-206, https://doi.org/10.1016/j.earscirev.2010.04.002, 2010.

Fritz, M., Wetterich, S., Schirrmeister, L., Meyer, H., Lantuit, H., Preusser, F., and Pollard, W. H.: Eastern Beringia and beyond: Late Wisconsinan and Holocene landscape dynamics along the Yukon Coastal Plain,
Canada, Paleogeogr. Paleoclimatol. Paleoecol., 319, 28-45, https://doi.org/10.1016/j.palaeo.2011.12.015, 2012.

Galbraith, R. F., Roberts, R. G., Laslett, G. M., Yoshida, H., and Olley, J. M.: Optical dating of single and multiple grains of quartz from jinmium rock shelter, northern Australia, part 1, Experimental design and statistical models, Archaeometry, 41, 339364, https://doi.org/10.1111/j.1475-4754.1999.tb00987.x, 1999.

Ganopolski, A. and Calov, R.: The role of orbital forcing, carbon dioxide and regolith in $100 \mathrm{kyr}$ glacial cycles, Clim. Past, 7, 1415-1425, https://doi.org/10.5194/cp-7-1415-2011, 2011.

Goslar, T., Czernik, J., and Goslar, E.: Low-energy C-14 AMS in Poznan Radiocarbon Laboratory, Poland, Nucl. Instrum. Meth. B, 223, 5-11, https://doi.org/10.1016/j.nimb.2004.04.005, 2004.

Gravis, G.: Cyclicity of thermokarst at the coastal lowlands during the late Pleistocene and Holocene, Publications of the 3rd International Conference on Permafrost, 10-13 July 1978, Edmonton, Canada, 283-287, 1978.

Grootes, P. M., Nadeau, M. J., and Rieck, A.: C-14AMS at the Leibniz-Labor: radiometric dating and isotope research, Nucl. Instrum. Meth. B, 223, 55-61, https://doi.org/10.1016/j.nimb.2004.04.015, 2004.

Günther, F., Overduin, P. P., Sandakov, A. V., Grosse, G., and Grigoriev, M. N.: Short- and long-term thermo-erosion of ice-rich permafrost coasts in the Laptev Sea region, Biogeosciences, 10, 4297-4318, https://doi.org/10.5194/bg-10-4297-2013, 2013.

Huntley, D. and Baril, M.: The K content of the K-feldspars being measured in optical dating or in thermoluminescence dating, Ancient TL, 15, 11-13, 1997.

Ivanov, O.: Stratigraphy and correlation of Neogene and Quaternary deposits in subarctic plains of East Yakutia, in: Problemy izucheniya chetvertichnogo perioda (Problems of the Quaternary Period Study), Nauka, Moscow, Russia, 202-211, 1972.

Kaplina, T.: Alasnye kompleksy Severnoi Yakutii (Alas complex of Northern Yakutia), Kriosfera Zemli, 13, 3-17, 2009.

Kaplina, T. N. and Lozhkin, A. V.: Age and History of Accumulation of the Ice Complex of the Maritime Lowlands of Yakutiya, in: Late Quaternary Environments of the Soviet Union, edited by: Velichko, A. A., Wright, H. E., and Barnosky, C. W., NED - New edition ed., University of Minnesota Press, Minneapolis, USA, 147-152, 1984.

Kienast, F., Wetterich, S., Kuzmina, S., Schirrmeister, L., Andreev, A. A., Tarasov, P., Nazarova, L., Kossler, A., Frolova, L., and Kunitsky, V. V.: Paleontological records indicate the occurrence of open woodlands in a dry inland climate at the present-day Arctic coast in western Beringia during the Last Interglacial, Quaternary Sci. Rev., 30, 2134-2159, https://doi.org/10.1016/j.quascirev.2010.11.024, 2011.

Konishchev, V. and Kolesnikov, S.: Osobennosti stroeniya i sostava pozdnekainozoiskikh otlozheniyakh $\mathrm{v}$ obnazhenii Oyagosskii Yar (Peculiarities of structure and composition of late Cenozoic deposits in the section of Oyogossky Yar). Problemy Kriolitologii (Problems of Cryolithology), Moscow University Press, Moscow, Russia, IX, 107-117, 1981.

Krbetschek, M. R., Gotze, J., Dietrich, A., and Trautmann, T.: Spectral information from minerals relevant for luminescence dating, Radiat. Meas., 27, 695-748, https://doi.org/10.1016/S13504487(97)00223-0, 1997. 
Kreutzer, S., Schmidt, C., Fuchs, M. C., Dietze, M., Fischer, M., and Fuchs, M.: Introducing an R package for luminescence dating analysis, Ancient TL, 30, 1-8, 2012.

Kulig, G.: Erstellung einer Auswertesoftware zur Altersbestimmung mittels Lumineszenzverfahren unter spezieller Beruecksichtigung radioaktiver Ungleichgewichte in der 238U-Zerfallsreihe, BSc, Faculty of Mathematics and Network Computing, TU Bergakademie Freiberg, Freiberg, Germany, 2005.

Kunitsky, V.: Khimicheskii sostav ledinykh zhil ledovogo kompleksa (Chemical composition of continuous grown ice-wedges of the Ice Complex), in: Cryolithozone and Groundwater of Siberia, Part I: Morphology of the Cryolithozone, edited by: Klimovski, I., Shepelev, V., and Lyubomirov, A., Melnikov Permafrost Institute Publishing, Yakutsk, Russia, 93-117, 1996.

Lachenbruch, A. H.: Mechanics of Thermal Contraction Cracks and Ice-Wedge Polygons in Permafrost, Geol. S. Am. S., 70, 1-66, https://doi.org/10.1130/SPE70-p1, 1962.

Lachniet, M. S., Lawson, D. E., and Sloat, A. R.: Revised C14 dating of ice wedge growth in interior Alaska (USA) to MIS 2 reveals cold paleoclimate and carbon recycling in ancient permafrost terrain, Quaternary Res., 78, 217-225, https://doi.org/10.1016/j.yqres.2012.05.007, 2012.

Laskar, J., Robutel, P., Joutel, F., Gastineau, M., Correia, A. C. M., and Levrard, B.: A long-term numerical solution for the insolation quantities of the Earth, Astron. Astrophys., 428, 261-285, https://doi.org/10.1051/0004-6361:20041335, 2004.

Leffingwell, E. D. K.: Ground-ice wedges - The dominant form of ground ice on the north coast of Alaska, J. Geol., 23, 635-654, 1915.

Mackay, J. R.: Oxygen isotope variations in permafrost, Tuktoyaktuk Peninsula area, Northwest Territories, Current Research, Part B, Geological Survey of Canada, Paper 83-1B, 67-74, 1983.

Merlivat, L. and Jouzel, J.: Global Climatic Interpretation of the Deuterium-Oxygen 18 Relationship for Precipitation, J. Geophys. Res.-Oc. Atm., 84, 5029-5033, https://doi.org/10.1029/JC084iC08p05029, 1979.

Meyer, H., Schönicke, L., Wand, U., Hubberten, H. W., and Friedrichsen, H.: Isotope studies of hydrogen and oxygen in ground ice - Experiences with the equilibration technique, Isot. Environ. Health Stud., 36, 133-149, https://doi.org/10.1080/10256010008032939, 2000.

Meyer, H., Dereviagin, A. Y., Siegert, C., and Hubberten, H.W.: Paleoclimate studies on Bykovsky Peninsula, North Siberiahydrogen and oxygen isotopes in ground ice, Polarforschung, 70, 37-51, 2002a.

Meyer, H., Dereviagin, A. Y., Siegert, C., Schirrmeister, L., and Hubberten, H. W.: Palaeoclimate reconstruction on Big Lyakhovsky Island, North Siberia - Hydrogen and oxygen isotopes in ice wedges, Permafrost Periglac., 13, 91-105, https://doi.org/10.1002/ppp.416, 2002b.

Meyer, H., Schirrmeister, L., Andreev, A., Wagner, D., Hubberten, H. W., Yoshikawa, K., Bobrov, A., Wetterich, S., Opel, T., Kandiano, E., and Brown, J.: Lateglacial and Holocene isotopic and environmental history of northern coastal Alaska - Results from a buried ice-wedge system at Barrow, Quaternary Sci. Rev., 29, 3720-3735, https://doi.org/10.1016/j.quascirev.2010.08.005, 2010a.
Meyer, H., Schirrmeister, L., Yoshikawa, K., Opel, T., Wetterich, S., Hubberten, H. W., and Brown, J.: Permafrost evidence for severe winter cooling during the Younger Dryas in northern Alaska, Geophys. Res. Lett., 37, L03501, https://doi.org/10.1029/2009g1041013, 2010b.

Meyer, H., Opel, T., Laepple, T., Dereviagin, A. Y., Hoffmann, K., and Werner, M.: Long-term winter warming trend in the Siberian Arctic during the mid-to late Holocene, Nat. Geosci., 8, 122-125, https://doi.org/10.1038/ngeo2349, 2015.

Michel, F. A.: Isotope investigations of permafrost waters in northern Canada, Department of Earth Sciences, University of Waterloo, Waterloo, Canada, 1982.

Murray, A. S. and Wintle, A. G.: Luminescence dating of quartz using an improved single-aliquot regenerative-dose protocol, Radiat. Meas., 32, 57-73, https://doi.org/10.1016/S13504487(99)00253-X, 2000.

Murray, A. S. and Wintle, A. G.: The single aliquot regenerative dose protocol: potential for improvements in reliability, Radiat. Meas., 37, 377-381, https://doi.org/10.1016/S13504487(03)00053-2, 2003.

Murton, J. B.: Ground Ice and Cryostratigraphy, in: Treatise on Geomorphology, edited by: Shroder, J. F. (editor-in-chief), Giardino, R., and Harbor, J. (volume eds.), Academic Press, San Diego, USA, 173-201, 2013.

Murton, J. B. and French, H. M.: Cryostructures in Permafrost, Tuktoyaktuk Coastlands, Western Arctic Canada, Can. J. Earth Sci., 31, 737-747, https://doi.org/10.1139/e94-067, 1994.

Nagaoka, D., Saijo, K., and Fukuda, M.: Sedimental environment of the Edoma in high Arctic eastern Siberia, Proceedings of the Third Symposium on the joint Siberian permafrost Studies between Japan and Russia in 1994, 30-31 January 1995, Tsukuba, Japan, 8-13, 1995.

North Greenland Ice Core Project members: High-resolution record of Northern Hemisphere climate extending into the last interglacial period, Nature, 431, 147-151, https://doi.org/10.1038/nature02805, 2004.

Opel, T., Dereviagin, A. Y., Meyer, H., Schirrmeister, L., and Wetterich, S.: Palaeoclimatic Information from Stable Water Isotopes of Holocene Ice Wedges on the Dmitrii Laptev Strait, Northeast Siberia, Russia, Permafrost Periglac., 22, 84-100, https://doi.org/10.1002/ppp.667, 2011.

Opel, T., Laepple, T., Meyer, H., Dereviagin, A., and Wetterich, S.: Northeast Siberian ice wedges confirm Arctic winter warming over the past two millennia, The Holocene, https://doi.org/10.1177/0959683617702229, online first, 2017a.

Opel, T., Wetterich, S., Meyer, H., Dereviagin, A. Y., Fuchs, M. C., and Schirrmeister, L.: Gravimetric ice content of sediment samples and stable isotope characteristics for ice wedges and for pore and segregrated ice at the Oyogos Yar coast, Northeast Siberian Arctic, https://doi.org/10.1594/PANGAEA.875146, 2017b.

Petoukhov, V., Ganopolski, A., Brovkin, V., Claussen, M., Eliseev, A., Kubatzki, C., and Rahmstorf, S.: CLIMBER-2: a climate system model of intermediate complexity. Part I: model description and performance for present climate, Clim. Dynam., 16, 1-17, https://doi.org/10.1007/P100007919, 2000.

Porter, T. J., Froese, D. G., Feakins, S. J., Bindeman, I. N., Mahony, M. E., Pautler, B. G., Reichart, G. J., Sanborn, P. T., Simpson, M. J., and Weijers, J. W. H.: Multiple water isotope proxy reconstruction of extremely low last glacial temperatures in Eastern 
Beringia (Western Arctic), Quaternary Sci. Rev., 137, 113-125, https://doi.org/10.1016/j.quascirev.2016.02.006, 2016.

Reimer, P. J., Bard, E., Bayliss, A., Beck, J. W., Blackwell, P. G., Bronk Ramsey, C., Buck, C. E., Cheng, H., Edwards, R. L., Friedrich, M., Grootes, P. M., Guilderson, T. P., Haflidason, H., Hajdas, I., Hatte, C., Heaton, T. J., Hoffmann, D. L., Hogg, A. G., Hughen, K. A., Kaiser, K. F., Kromer, B., Manning, S. W., Niu, M., Reimer, R. W., Richards, D. A., Scott, E. M., Southon, J. R., Staff, R. A., Turney, C. S. M., and van der Plicht, J.: IntCal13 and Marine13 Radiocarbon Age Calibration Curves 050000 Years cal BP, Radiocarbon, 55, 1869-1887, 2013.

Rethemeyer, J., Fulop, R. H., Hofle, S., Wacker, L., Heinze, S., Hajdas, I., Patt, U., Konig, S., Stapper, B., and Dewald, A.: Status report on sample preparation facilities for $\mathrm{C}-14$ analysis at the new CologneAMS center, Nucl. Instrum. Meth. B, 294, 168-172, https://doi.org/10.1016/j.nimb.2012.02.012, 2013.

Romanovskii, N. N.: Novye dannye o stroenii chetvertichnykh otlozhenii ostrova Bol'shogo Lyakhovskogo, Novosibirskie ostrova (New data about Quaternary deposits structure on the Bol'shoy Lyakhovsky Island, New Siberian Islands). Nauchnye doklady vysshei shkoly. Seriya geologogeograficheskaya (Scientific Notes of the Higher School. Geological-Geographical Series), 2, 243-248, 1958a.

Romanovskii, N. N.: Merzlotnye structury oblekaniya v chetvertichnykh otlozheniyakh (Permafrost structures in Quaternary deposits), Nauchnye doklady vysshei shkoly. Seriya geologogeograficheskaya (Scientific Notes of the Higher School. Geological-Geographical Series), 3, 185-189, 1958b.

Romanovskii, N. N.: Paleogeograficheskie usloviya obrazovaniya chetvertichnykh otlozhenii ostrova Bol'shogo Lyakhovskogo, Novosibirskie ostrova (Paleogeographical conditions of formation of the Quaternary deposits on the Bol'shoy Lyakhovsky Island, New Siberian Islands), Voprosy fizicheskoi geografii polyarnykh stran (Questions of Physical Geography in Polar regions), 1, 80-88, 1958c.

Rudaya, N., Protopopov, A., Trofimova, S., Plotnikov, V., and Zhilich, S.: Landscapes of the 'Yuka' mammoth habitat: A palaeobotanical approach, Rev. Palaeobot. Palyno., 214, 1-8, https://doi.org/10.1016/j.revpalbo.2014.12.003, 2015.

Schirrmeister, L., Oezen, D., and Geyh, M. A.: Th230/U dating of frozen peat, Bol'shoy Lyakhovsky Island (Northern Siberia), Quaternary Res., 57, 253-258, https://doi.org/10.1006/qres.2001.2306, 2002a.

Schirrmeister, L., Siegert, C., Kunitzky, V. V., Grootes, P. M., and Erlenkeuser, H.: Late Quaternary ice-rich permafrost sequences as a paleoenvironmental archive for the Laptev Sea Region in northern Siberia, Int. J. Earth Sci., 91, 154-167, https://doi.org/10.1007/s005310100205, 2002 b.

Schirrmeister, L., Grosse, G., Kunitsky, V., Meyer, H., Derivyagin, A., and Kuznetsova, T.: Permafrost, periglacial and paleoenvironmental studies on New Siberian Islands, in: RussianGerman Cooperation System Laptev Sea The Expeditions Lena 2002, edited by: Grigoriev, M., Rachold, V., Bolshiyanov, D., Pfeiffer, E., Schirrmeister, L., Wagner, D., and Hubberten, H., Reports on Polar and Marine Research, Alfred Wegener Institute for Polar and Marine Research, Bremerhaven, Germany, 195314, 2003a.

Schirrmeister, L., Grosse, G., Schwamborn, G., Andreev, A. A., Meyer, H., Kunitsky, V. V., Kuznetsova, T. V., Dorozhkina, M. V.,
Pavlova, E. Y., Bobrov, A. A., and Oezen, D.: Late Quaternary History of the Accumulation Plain North of the Chekanovsky Ridge (Lena Delta, Russia): A Multidisciplinary Approach, Polar Geography, 27, 277-319, https://doi.org/10.1080/789610225, 2003 b.

Schirrmeister, L., Grosse, G., Kunitsky, V., Magens, D., Meyer, H., Dereviagin, A., Kuznetsova, T., Andreev, A., Babiy, O., Kienast, F., Grigoriev, M., Overduin, P. P., and Preusser, F.: Periglacial landscape evolution and environmental changes of Arctic lowland areas for the last 60000 years (western Laptev Sea coast, Cape Mamontov Klyk), Polar Res., 27, 249-272, https://doi.org/10.1111/j.1751-8369.2008.00067.x, 2008a.

Schirrmeister, L., Wetterich, S., Kunitsky, V., Tumskoy, V., Dobrynin, D., Derevyagyn, A., Opel, T., Kienast, F., Kuznetsova, T., and Gorodinsky, A.: Palaeoenviromental studies on the Oyogos Yar coast, in: The Expedition LENA - NEW SIBERIAN ISLANDS 2007 during the International Polar Year (IPY) 2007/2008, edited by: Boike, J., Bol'shiyanov, D., Schirrmeister, L., and Wetterich, S., Reports on Polar and Marine Research, Alfred Wegener Institute for Polar and Marine Research, Bremerhaven, Germany, 85-154, 2008 b.

Schirrmeister, L., Grosse, G., Schnelle, M., Fuchs, M., Krbetschek, M., Ulrich, M., Kunitsky, V., Grigoriev, M., Andreev, A., Kienast, F., Meyer, H., Babiy, O., Klimova, I., Bobrov, A., Wetterich, S., and Schwamborn, G.: Late Quaternary paleoenvironmental records from the western Lena Delta, Arctic Siberia, Paleogeogr. Paleoclimatol. Paleoecol., 299, 175-196, https://doi.org/10.1016/j.palaeo.2010.10.045, 2011a.

Schirrmeister, L., Kunitsky, V., Grosse, G., Wetterich, S., Meyer, H., Schwamborn, G., Babiy, O., Derevyagin, A., and Siegert, C.: Sedimentary characteristics and origin of the Late Pleistocene Ice Complex on north-east Siberian Arctic coastal lowlands and islands - A review, Quat. Int., 241, 3-25, https://doi.org/10.1016/j.quaint.2010.04.004, 2011 b.

Schirrmeister, L., Froese, D., Tumskoy, V., Grosse, G., and Wetterich, S.: Yedoma: Late Pleistocene Ice-Rich Syngenetic Permafrost of Beringia, in: Encyclopedia of Quaternary Science (Second Edition), edited by: Elias, S. A., Elsevier, Amsterdam, the Netherlands, 542-552, 2013.

Schirrmeister, L., Meyer, H., Andreev, A., Wetterich, S., Kienast, F., Bobrov, A., Fuchs, M., Sierralta, M., and Herzschuh, U.: Late Quaternary paleoenvironmental records from the Chatanika River valley near Fairbanks (Alaska), Quaternary Sci. Rev., 147, 259-278, https://doi.org/10.1016/j.quascirev.2016.02.009, 2016.

Schwamborn, G., Meyer, H., Fedorov, G., Schirrmeister, L., and Hubberten, H. W.: Ground ice and slope sediments archiving late Quaternary paleoenvironment and paleoclimate signals at the margins of El'gygytgyn Impact Crater, NE Siberia, Quaternary Res., 66, 259-272, https://doi.org/10.1016/j.yqres.2006.06.007, 2006.

St-Jean, M., Lauriol, B., Clark, I. D., Lacelle, D., and Zdanowicz, C.: Investigation of Ice-Wedge Infilling Processes using Stable Oxygen and Hydrogen Isotopes, Crystallography and Occluded Gases (O(2), N(2), Ar), Permafrost Periglac., 22, 49-64, https://doi.org/10.1002/ppp.680, 2011.

Streletskaya, I. D., Vasiliev, A. A., Oblogov, G. E., and Tokarev, I. V.: Reconstruction of paleoclimate of Russian Arctic in the Late Pleistocene-Holocene on the basis of isotope study of ice wedges, Kriosfera Zemli, 19, 86-94, 2015. 
Stuiver, M. and Polach, H. A.: Reporting of 14C Data - Discussion, Radiocarbon, 19, 355-363, 1977.

Tomirdiaro, S. V.: Periglacial Landscapes and Loess Accumulation in the Late Pleistocene Arctic and Subarctic, in: Late Quaternary Environments of the Soviet Union, edited by: Velichko, A. A., Wright, H. E., and Barnosky, C. W., NED - New edition ed., University of Minnesota Press, Minneapolis, USA, 141-146, 1984.

Tumskoy, V.: Osobennosti kriolitogeneza otlozhenii severnoi Yakutii v srednem Neopleistotsene-Golotsene (Peculiarities of cryolithogenesis in northern Yakutia from the Middle Neopleistocene to the Holocene), Kriosfera Zemli, 16, 12-21, 2012.

Vaikmäe, R.: Oxygen isotopes in permafrost and ground ice: A new tool for paleoclimatic investigations, 5th Working Meeting Isotopes in Nature, 25-29 September 1989, Leipzig, Germany, Proceedings, 543-553, 1989.

Van Everdingen, R. E.: Multi-language glossary of permafrost and related ground-ice terms (revised 2005), National Snow and Ice Data Center/World Data Center for Glaciology, Boulder, USA, 1998.

Vasil'chuk, Y. and Vasil'chuk, A.: Spatial distribution of mean winter air temperatures in Siberian permafrost at 20$18 \mathrm{kaBP}$ using oxygen isotope data, Boreas, 43, 678-687, https://doi.org/10.1111/bor.12033, 2014.

Vasil'chuk, Y. K.: Syngenetic Ice Wedges: Cyclical Formation, Radiocarbon Age and Stable Isotope Records by Yurij K. Vasil'chuk, Moscow University Press, Moscow, 2006. 404 pp. ISBN 5-211-05212-9, Permafrost Periglac., 24, 82-93, https://doi.org/10.1002/ppp.1764, 2013.

Vasil'chuk, Y. K., van der Plicht, J., Jungner, H., Sonninen, E., and Vasil'chuk, A. C.: First direct dating of Late Pleistocene ice-wedges by AMS, Earth Planet. Sci. Lett., 179, 237-242, https://doi.org/10.1016/S0012-821X(00)00122-9, 2000.

Vasil'chuk, Y. K., Vasil'chuk, A. C., Rank, D., Kutschera, W., and Kim, J. C.: Radiocarbon dating of $\delta 18 \mathrm{O}-\delta \mathrm{D}$ plots in Late Pleistocene ice-wedges of the Duvanny Yar (Lower Kolynia River, Northern Yakutia), Radiocarbon, 43, 541-553, 2001.

von Toll, E.: Iskopaemye ledniki Novo-Sibirskikh ostrovov, ikh otnoshenie $\mathrm{k}$ trupam mamontov ik lednikovomu periodu (Ancient glaciers of New Siberian Islands, their relation to mammoth corpses and the Glacial period), Zapiski Imperatorskogo Russkogo Geograficheskogo obshestva po obshei geografii (Notes of the Russian Imperial Geographical Society), 32, 1$137,1897$.
Walter, K. M., Edwards, M. E., Grosse, G., Zimov, S. A., and Chapin, F. S.: Thermokarst lakes as a source of atmospheric CH4 during the last deglaciation, Science, 318, 633-636, https://doi.org/10.1126/science.1142924, 2007.

Wetterich, S., Kuzmina, S., Andreev, A. A., Kienast, F., Meyer, H., Schirrmeister, L., Kuznetsova, T., and Sierralta, M.: Palaeoenvironmental dynamics inferred from late Quaternary permafrost deposits on Kurungnakh Island, Lena Delta, Northeast Siberia, Russia, Quaternary Sci. Rev., 27, 1523-1540, https://doi.org/10.1016/j.quascirev.2008.04.007, 2008.

Wetterich, S., Schirrmeister, L., Andreev, A. A., Pudenz, M., Plessen, B., Meyer, H., and Kunitsky, V. V.: Eemian and Late Glacial/Holocene palaeoenvironmental records from permafrost sequences at the Dmitry Laptev Strait (NE Siberia, Russia), Paleogeogr. Paleoclimatol. Paleoecol., 279, 73-95, https://doi.org/10.1016/j.palaeo.2009.05.002, 2009.

Wetterich, S., Rudaya, N., Tumskoy, V., Andreev, A. A., Opel, T., Schirrmeister, L., and Meyer, H.: Last Glacial Maximum records in permafrost of the East Siberian Arctic, Quaternary Sci. Rev., 30, 3139-3151, https://doi.org/10.1016/j.quascirev.2011.07.020, 2011.

Wetterich, S., Tumskoy, V., Rudaya, N., Andreev, A. A., Opel, T., Meyer, H., Schirrmeister, L., and Huls, M.: Ice Complex formation in arctic East Siberia during the MIS3 Interstadial, Quaternary Sci. Rev., 84, 39-55, https://doi.org/10.1016/j.quascirev.2013.11.009, 2014.

Wetterich, S., Tumskoy, V., Rudaya, N., Kuznetsov, V., Maksimov, F., Opel, T., Meyer, H., Andreev, A. A., and Schirrmeister, L.: Ice Complex permafrost of MIS5 age in the Dmitry Laptev Strait coastal region (East Siberian Arctic), Quaternary Sci. Rev., 147, 298-311, https://doi.org/10.1016/j.quascirev.2015.11.016, 2016.

Wolff, E. W., Chappellaz, J., Blunier, T., Rasmussen, S. O., and Svensson, A.: Millennial-scale variability during the last glacial: The ice core record, Quaternary Sci. Rev., 29, 2828-2838, https://doi.org/10.1016/j.quascirev.2009.10.013, 2010. 